\title{
A köztisztviselöi törvények hatása a kormányzati kiadásokra
}

Fontos-e, hogy a bürokrácia független legyen a politikától? Milyen hatással járnak azok a törvények, amelyek a politikusok és a bürokrácia kapcsolatát szorosabbá teszik vagy lazítják? Ezek alapvető kérdések a modern államok szervezésével kapcsolatban, mégis viszonylag keveset tudunk róluk. Ebben a cikkben a témakör egy szeletével foglalkozom: a köztisztviselői törvények hatásaival. Összefoglalok néhány közelmúltbeli elméleti és empirikus eredményt, és rövid áttekintést nyújtok az idevágó közgazdasági és politikatudományi irodalomról.*

Journal of Economic Literature (JEL) kód: D72, D73, E62, H11, H72.

\section{Bevezető}

A modern demokráciákban a bürokrácia szervezésének egyik fö eleme valamilyen típusú köztisztviselői (civil service) rendszer. Egy ilyen rendszer előírja, hogy a bürokraták bizonyos csoportjának politikailag semlegesnek kell lennie, a felvételnél, az elbocsátásnál és a bérezésnél szakmai és nem pedig politikai szempontoknak kell érvényesülnie, és a hatalmon lévő politikusok nem várhatnak el politikai szolgáltatásokat a bürokratáktól. ${ }^{1}$ Emellett minden országban vannak a köztisztviselöi rendszeren kívül, patronázsrendszerben müködő bürokraták is. Ebben a rendszerben a bürokraták az őket kinevező politikustól függnek, a felvételnél, az elbocsátásnál és a bérezésnél politikai szempontok érvényesülnek, és a politikai szolgáltatások nyújtása a munka része.

Ebben a cikkben bemutatok néhány friss elméleti és empirikus eredményt a kétfajta rendszer - a köztisztviselői rendszer és a patronázsrendszer - közötti választással kapcsolatban, és rövid áttekintést nyújtok az idevágó közgazdasági

* A cikk a Magyar Közgazdaságtudományi Egyesület 2016. évi konferenciáján elhangzott plenáris előadás kibővített változata. Köszönöm az MKE meghívását és a résztvevők hozzászólásait.

${ }^{1}$ Az állami alkalmazottaknak sokféle csoportja létezik, és ezekre különböző szabályok vonatkozhatnak. Itt „bürokrataként” hivatkozom minden kinevezett (és nem pedig választott) állami alkalmazottra, és a szabályok részleteit később tárgyalom.

Ujhelyi Gergely, University of Houston, Közgazdaságtan Tanszék. 
és politikatudományi irodalomról. Bár a módszertan általános érvényü, az elemzés hátteréül amerikai adatok szolgálnak, és ezt tükrözik a tárgyalt példák és nagyrészt a hivatkozott irodalom is. Az itt leírtak alkalmazását magyar vagy más esetekre az olvasóra és a jövőbeli kutatásokra bízom.

Az Egyesült Államokban a 19. század végéig a bürokrácia egésze patronázsrendszerben müködött. Az első reformhullám az 1883-as Pendleton-törvénnyel kezdődött, amely szövetségi szinten teremtette meg a köztisztviselöi rendszert. Bevezette a köztisztviselői vizsgát, megtiltotta a politikai szempontú elbocsátásokat, és létrehozott egy független „Köztisztviselői Bizottságot” a rendszer müködésének ellenőrzésére. A következő 100 évben ezt a rendszert fokozatosan átvették a tagállamok és a helyi (megyei, városi) önkormányzatok. Az elmúlt 30-40 évet egy második reformhullám jellemezte, amely a köztisztviselöi rendszer lazítását eredményezte. Ez a hullám is szövetségi szintről indult, az 1978-as Civil Service Reform Act törvénnyel, amely a hangsúlyt a bürokrácia irányíthatóságára és rugalmasságára helyezte, és növelte a bürokraták feletti politikai kontrollt. Később hasonló irányú reformok indultak állami és helyi szinteken, például 1996-ban Georgia állam megszüntette az élethosszig tartó kinevezést, és hasonló intézkedések születtek például Floridában 2001-ben és Arizonában 2012-ben. A politika és a bürokrácia közötti optimális határvonal jelenleg is nyitott kérdés. ${ }^{2}$

Elméletileg a köztisztviselői rendszer (független bürokrácia) és a patronázsrendszer (politikai kontroll alatt álló bürokrácia) közötti választásnál két alapvető átváltás érvényesül. Az első átváltás, hogy egy független bürokrata kevésbé fog reagálni a politikus utasítására - akkor is, ha az utasítás rossz, de akkor is, ha jó. Ezért bár a függetlenség értékes lehet, ha egy jó (a közjót szem elött tartó) bürokratát megvéd egy rossz (a közjóval szemben a saját érdekét érvényesítö) politikus befolyásától, de költséges akkor, ha egy rossz bürokrata irányítását nehezíti meg egy jó politikus számára. Ez az átváltás jól ismert az irodalomban, és általában alapjául szolgál a bürokrácia szabályozásával kapcsolatos gyakorlati vitáknak. Például az első amerikai reformhullám, amely erősíteni kívánta a köztisztviselői rendszert, a jó bürokraták függetlenségét hangsúlyozta. Ezzel szemben a második reformhullám a rugalmatlan és alacsony hatékonyságú (vagyis rossz) bürokrácia függetlenségének költségeit kívánta csökkenteni a köztisztviselöi törvények lazításával.

A köztisztviselöi rendszerrel kapcsolatos második átváltás kevésbé közvetlen, mint az első, de az alábbiakban amellett fogok érvelni, hogy legalább annyira fontos lehet. Ha a bürokraták máshogy viselkednek köztisztviselői rendszer és patronázsrendszer alatt, akkor előfordulhat, hogy a politikusok ösztönzői is mások lesznek a két rendszerben. Tekintsünk egy rossz politikust, aki a közjó rovására a saját érdekeit próbálja érvényesíteni. Jövőre egy nagy autópálya-építési beruházás esedékes, és a politikus tudja, hogy ha teljes kontrollja van a beruházást lebonyolító bürokrata fölött, akkor a közjó rovására nagy haszna származhat a beruházásból (például valamilyen korrupció formájában). Ha az idei választásokon múlik, hogy a politikus jövőre hivatalban lesz-e és

\footnotetext{
${ }^{2}$ A kérdés különösen nagy nyilvánosságot kapott, amikor Trump elnök 2017 elején - hivatalba lépése után - látványosan növelte a politikai kontrollt számos bürokratával szemben (például minisztériumi dolgozókkal, helyettes igazságügyminiszterrel, FBI-igazgatóval).
} 
realizálhatja-e ezt a hasznot, érdekében áll kedvezni a szavazóknak, hogy újraválasszák. Vagyis ösztönzése van rá, hogy ma a közjót szolgáló döntéseket hozzon, amennyiben ez növeli az újraválasztás valószínüségét.

Tekintsük most ugyanezt a politikust egy köztisztviselöi rendszerben! A politikus tudja, hogy az autópálya-beruházást független bürokrata fogja irányítani, és nem lesz lehetősége rá, hogy hasznot húzzon belöle. Például ha befolyásolni próbálja a bürokratát a vállalkozók pályáztatásánál, nem fog sikerrel járni. Ebben az esetben a politikus számára sokkal kevésbé vonzó az újraválasztás, és ezért kevésbé van ösztönözve rá, hogy a szavazóknak kedvezzen. Elöfordulhat, hogy ezért ma a közjóval ellentétes döntéseket fog hozni.

Ez a példa szemlélteti a második átváltást, amely releváns lehet a köztisztviselői és a patronázsrendszer közötti választásnál: a bürokrata függetlenségének növelése rossz irányba befolyásolhatja a politikus viselkedését. Az alábbiakban bemutatott modell formalizálja ezt a lehetőséget, és további hasonló átváltásokra is fényt derít a bürokrata és a politikus „minősége” között.

A köztisztviselői és a patronázsrendszer közti választás tehát hatással lehet a bürokraták (első átváltás) és a politikusok (második átváltás) viselkedésére és minőségére. Hogyan lehetne ezeket a hatásokat empirikusan elemezni? Az ideális kísérlet valahogy a következőképpen nézne ki. Rendelkezésünkre állna egy sor egymással összehasonlítható államigazgatási rendszer, hasonló döntési helyzetekben lévő politikusokkal és bürokratákkal. Az államigazgatási rendszerek egy részében véletlenszerűen bevezetnénk a köztisztviselői rendszert, míg a többit patronázs alapján szerveznénk. Ezután megmérnénk a bürokrácia teljesítményét és a politikusok viselkedését a köztisztviselöi és a patronázsrendszerekben. Mivel a rendszereket véletlenszerủen vezettük be, a kimenetekben tapasztalt különbségek a rendszer oksági hatását tükröznék.

Ahogyan az intézményi változások hatásainak elemzésekor ez általában lenni szokott, ez az ideális kísérlet nyilvánvalóan nem valósítható meg. A két fö nehézség a rendszer véletlenszerü bevezetése és a kimenetek mérése - az utóbbi akkor is problémát jelent, ha valamilyen ügyes identifikációs stratégiával meg tudjuk közelíteni a rendszer véletlenszerü bevezetését. Az alábbiakban részletesen tárgyalok két tanulmányt (Ujhelyi [2014a], [2014b]), ahol az amerikai tagállamok köztisztviselöi reformjainak hatásait vizsgáltam. Ennek a környezetnek nagy előnye, hogy lehetséges egymással összehasonlítható államigazgatásokat vizsgálni. Bár a reformok nem történtek véletlenszerűen, terjedelmes leíró irodalom létezik a reformhullám különböző okairól, és ezekre lehetséges kontrollálni a hatásvizsgálat során. A kimeneteket (bürokraták, politikusok viselkedését) megmérni itt is nehéz, de egy bizonyos kimenetről, a kormányzati kiadások különböző csoportjairól részletes adatok állnak rendelkezésre az amerikai statisztikai hivatal jóvoltából.

Az empirikus eredmények példát mutatnak a fent említett második átváltás érvényesülésére a gyakorlatban. A köztisztviselöi törvények hatására a politikusok más döntéseket hoznak az állami kiadásokról. Az első tanulmányban azt látjuk, hogy a tagállami szintü köztisztviselői rendszer bevezetésének hatására nőnek az önkormányzatokhoz irányuló kormányközi transzferek. A kormányzati kiadások 
megkerülik a megreformált, immár független állami bürokráciát, és helyette alacsonyabb, a reformok által nem értintett önkormányzatoknál kötnek ki.

A második tanulmányban a köztisztviselői rendszer politikai költségvetési ciklusokra gyakorolt hatását vizsgáltam. A „politikai költségvetési ciklus” fogalom a kormányzati kiadások választási ciklusokhoz igazított mozgását írja le: a hatalmon lévő politikusok szeretnek a választások elött a szavazók kedvében járni és ennek megfelelő kiadásokat eszközölni (például útépítési beruházásokat a fontos választói körzetekben). Mivel ennek csak akkor van értelme, ha a politikus befolyásolni tudja, hogy a kiadás mikor és hol valósuljon meg, kisebb az ösztönzés a politikai költségvetési ciklusra, ha a kiadások felhasználásáról (például arról, hogy pontosan hol és hogyan épüljön meg az autóút) független bürokraták döntenek. Az adatok alátámasztják ezt a gondolatot az amerikai útépítési kiadások esetében. Ezekben a kiadásokban politikai ciklusokat találunk patronázsrendszerben, viszont nem találunk ilyen ciklusokat köztisztviselői rendszer esetén.

Összességében ezek az eredmények azt mutatják, hogy a bürokrácia és a politika közötti optimális határvonal meghúzása pontos elemzést kívánó, sokoldalú kérdés. A szabályozásnak a közvetlen hatások mellett figyelembe kell vennie a kevésbé nyilvánvaló második átváltáshoz kapcsolódó hatásokat is. Természetesen ez a cikk nem fogja megmondani, hogy a köztisztviselői vagy a patronázsrendszer ,jobb-e”. A cél mindössze az, hogy elméletileg és empirikusan egyaránt megalapozott megfontolásokat nyújtson az erről való gondolkodáshoz.

Az alábbiakban először áttekintem az idevágó közgazdasági és politikatudományi irodalom egy részét, majd bemutatok egy elméleti modellt a köztisztviselői rendszer hatásairól való gondolkodáshoz. Ezt követően ismertetem az empirikus eredményeket, végül pedig megemlítek néhány lehetséges jövőbeli kutatási irányt.

\section{Irodalmi áttekintés}

Más politikai szereplökhöz képest a bürokrácia meglehetősen elhanyagolt területnek számít mind a közgazdaságtanban, mind a politikatudományban. Például annak ellenére, hogy a kormányzati szektor tagjainak túlnyomó többsége bürokrata (vagyis kinevezett, nem pedig választott döntéshozó), a közgazdaságtan és a politikatudomány egyaránt sokkal nagyobb hangsúlyt fektet a politikusok tanulmányozására.

Az egyik kérdés, amelyiknek viszonylag nagyobb irodalma van, a választott és a kinevezett döntéshozók közötti választással kapcsolatos. Melyik közpolitikai területeket jobb választott döntéshozókra (politikusokra) bízni, és melyeket jobb kinevezett döntéshozókra (bürokratákra) hagyni? A közgazdasági irodalom ezt a kérdést a társadalmi tervező nézőpontjából szokta vizsgálni (például Maskin-Tirole [2004], Alesina-Tabellini [2007], Coate-Knight [2011], Vlaicu-Whalley [2016]), vagyis azt kérdezi, hogy jóléti szempontból mikor jobb az egyik vagy a másik intézményi megoldás. A politikatudomány ezzel szemben a politikus szempontjából közelíti meg a kérdést: mikor dönt úgy egy politikus, hogy magánál tartja a döntési jogkört, és mikor dönt úgy, hogy egy kinevezett bürokratához delegálja? (Lásd például Epstein-O'Halloran [1999], Gailmard-Patty [2007], Fox-Jordan [2011], Ting [2012].) 
Ennek a kérdésnek mind a közgazdasági, mind a politikatudományi megközelítésére érvényes, hogy a politikus és a bürokrata közötti választást tanulmányozza. E megközelítések egyike sem alkalmazható közvetlenül a köztisztviselöi rendszer vizsgálatára, hiszen ez a kérdés alapvetően a két szereplö kapcsolatáról szól, vagyis a problémában mindkét szereplö egyszerre van jelen. ${ }^{3}$

Mind a közgazdaságtan, mind a politikatudomány önmagában is vizsgálja a bürokráciát, figyelmen kívül hagyva a politikával való kapcsolatát. Itt a bürokrácia nem különbözik minőségileg más szervezetektől (például a vállalatoktól), és hasonló kérdések merülnek fel a működésével kapcsolatban, mint más szervezeteknél. Például: hogyan lehet a lehetö legjobb bürokratákat fölvenni és a munkájukat jó irányba ösztönözni (Besley-McLaren [1993], Prendergast [2007], Leaver [2009])? Az utóbbi néhány évben a kutatások különös figyelmet kezdtek szentelni az ilyen típusú kérdéseknek a fejlődő országokban, ahol a bürokrácia fejlesztése fontos feltétele lehet a gazdasági növekedésnek. Dal Bo és szerzötársai [2013] például Mexikóban, Bertrand és szerzötársai [2016] pedig Indiában vizsgálta a bürokraták kiválasztását és a hatékonyabb müködést elősegítő tényezőket.

A politikatudományban a bürokráciát mint önálló szervezetet vizsgáló tanulmányokat föleg az államigazgatási (public administration) kutatók jegyzik. Ezek jellemzően erősen leíró, legfeljebb minimális statisztikai elemzést tartalmazó dolgozatok, amelyeket sok politológus éppen ezért nem tekint a modern politikatudomány szerves részének.

Amint azt az alábbiakban részletesen bemutatom, a bürokráciát e megközelítések mellett érdemes a politikai rendszer részeként is megvizsgálni.

A köztisztviselöi rendszerek hatásainak empirikus elemzését sokáig megnehezítette a szükséges adatok hiánya az egymással összehasonlítható reformokról. Néhány korai dolgozat kizárólag keresztmetszeti adatokra hagyatkozott, ami nem teszi lehetővé a legalapvetőbb fix különbségek hatásának kiszürését sem (például Rauch-Evans [2000] és Krause és szerzötársai [2006]). Rauch [1995] az első olyan tanulmány, amelyik paneladatokat használt (amerikai városi reformokról), de a vizsgált időszakról (1902-1931) nem álltak rendelkezésre időben változó kontrollváltozók, így semmilyen időben változó tényezőre (népesség, gazdasági fejlődés, politikai változások) nem tud kontrollálni.

Az újabb kutatások sikeresen vizsgálták az amerikai tagállamok reformjait, ahol kiküszöbölhetők ezek az identifikációs problémák. Folke és szerzötársai [2011] a reformok megközelítőleges időpontját használva vizsgálta a politikai kimeneteket, és megmutatta, hogy a hatalmon lévő politikusok patronázslehetőségeik elvesztésének hatására kevésbé lesznek sikeresek a következő választáson. Ujhelyi [2014b] összegyüjti a reformok pontos időpontját, és ezek segítségével vizsgálja a kormányzati kiadásokra gyakorolt hatásukat (ezt a cikket az alábbiakban részletesen tárgyalom).

\footnotetext{
${ }^{3}$ Ezen túlmenően érdemes hangsúlyozni, hogy a bürokratához való delegálás alapvetően más jellegű döntés a köztisztviselői törvények bevezetéséhez képest. Az előbbi egy adott döntési helyzetet vagy politikust érint, és a delegálás sok politikusnak hatalmában áll. Az utóbbi egy átfogó intézményi döntés, amely egyszerre sok politikust és bürokratát érint, és az ilyen döntés meghozatalára kevés politikusnak van lehetősége.
} 
A köztisztviselöi rendszer - és a bürokráciát szabályozó egyéb törvények - hatásainak vizsgálata tágabban az intézmények hatásait elemző irodalomba tartozik (lásd például Besley-Case [2003] kiváló összefoglalóját az Egyesült Államok tagállamaival kapcsolatos kutatásokról). Miközben a választási intézményekkel (például szavazói regisztráció, választási körzetek, kampányfinanszírozás) és a döntéshozási intézményekkel (például törvények többségi vagy abszolút többségi jóváhagyása, elnöki vagy kormányzói vétó) ma már kiterjedt irodalom foglalkozik, a bürokratikus intézmények hatásairól még mindig nagyon keveset tudunk.

\section{Elméleti keret a köztisztviselői rendszer néhány hatásának elemzésére}

\section{A modell}

Ebben a szakaszban Ujhelyi [2014a] alapján leírok egy egyszerü modellt, amelynek segítségével lehetséges precízen gondolkodni a köztisztviselői törvények hatásairól, valamint a köztisztviselői rendszer és a patronázsrendszer közötti választásnál érvényesülö átváltásokról.

Két időszak van, és a kettő között választásokat tartanak. ${ }^{4}$ Egy hivatalban lévő politikus mindkét időszakban választ egy politikát, amelyet $E \in\{0,1\}$ jelöl. A politika végrehajtása egy bürokrata feladata. A bürokrata által végrehajtott politika $e \in\{0,1\}$. Ha $e=E$, a bürokrata engedelmeskedik a politikusnak, ha pedig $e \neq E$, akkor nem. A „politikát" itt nagyon tág értelemben használom: gyakorlatilag bármilyen döntést leírhat, amelynél egy politikus és egy bürokrata is szerepet játszik. Például a politikus megválaszthatja, hogy egy jóléti támogatást milyen kritériumok alapján kell szétosztani, a bürokrata pedig követheti a szabályokat, vagy eltérhet azoktól; vagy a politikus megkérheti a bürokratát, hogy egy közbeszerzési eljárásnál egy bizonyos pályázót részesítsen elönyben, a bürokrata pedig eldöntheti, hogy eleget tesz-e a kérésnek.

A szavazók jóléte szempontjából vagy a 0 , vagy az 1 politika a jobb, és ezt az $S \in\{0,1\}$ világállapot jelzi. A két világállapot valószínűsége egyforma, és a világállapot függetlenül realizálódik mindkét időszakban. A szavazók hasznossága mindkét időszakban

$$
U(e, S)= \begin{cases}\Delta, & \text { ha } e=S \\ 0, & \text { ha } e=1-S,\end{cases}
$$

ahol $\Delta$ egy pozitív paraméter. Ez alapján az $S$-sel megegyező politikát „jónak”, az $S$-töl különböző politikát pedig „rossznak” hívom. A diszkontfaktor $\beta$ (minden játékos számára ugyanaz).

A politikusnak két típusa van: Jó és Rossz. A jó politikus hasznossága a végrehajtott politikából megegyezik a szavazóéval, $V^{G P}(e, S)=U(e, S)$, vagyis a jó politikát preferálja. A rossz politikus ezzel szemben a rossz politikát preferálja. Az ő hasznossága

${ }^{4}$ A modell a politikai megbízó-ügynök modellek családjába tartozik, amelyről magyarul Besley [2012] nyújt összefoglalót. 
$V^{B P}(e, S)= \begin{cases}0, & \text { ha } e=S \\ R, & \text { ha } e=1-S,\end{cases}$

ahol $R$, a rossz politikus járadéka a rossz politikából egy valószínüségi változó, $G$ eloszlásfüggvénnyel a $[0, \infty)$ tartományon és $\bar{R}$ átlaggal. A politikusnak ezenkívül közvetlen hasznossága származhat abból, ha a bürokrata az általa választott politikát hajtja végre (vagy esetleg nem szereti, ha a bürokrata nem engedelmeskedik neki). Ezt úgy modellezzük, hogy a politikus hasznossága $V(E, e, S)=V(e, S)$, ha $e=E$, de $V(E, e, S)=\mu V(e, S)$, ha $e=1-E$, ahol $\mu \in(0,1)$. Minél kisebb a $\mu$, annál kevésbé szereti a politikus, ha a bürokrata nem engedelmeskedik neki. Végül a politikus abból is hasznosságot kap, hogy hatalmon van, és ezt $V_{0}$ jelöli. A jó politikus valószínüsége $\Pi$.

A bürokrata preferenciái eltérhetnek a politikusétól. Az egyik lehetőség, hogy saját preferenciákkal rendelkezik közvetlenül a politikával kapcsolatban (például Prendergast [2007]). A másik lehetőség, hogy karriermegfontolások vezérlik (például Alesina-Tabellini [2007]). Ebben a modellben az első megközelítést követem, de Ujhelyi [2014a] megmutatja, hogy az eredmények miként általánosíthatók a második helyzetre is. A bürokrata tehát szintén lehet jó vagy rossz. A jó bürokrata hasznossága megegyezik a szavazóéval, míg a rossz bürokrata hasznossága

$v(e, S)= \begin{cases}0, & \text { ha } e=S \\ r, & \text { ha } e=1-S .\end{cases}$

Az egyszerüség kedvéért $r$, a rossz bürokrata hasznossága a rossz politika végrehajtásából egy rögzített paraméter. Tegyük fel, hogy a rossz bürokrata nem „nagyon rossz" abban az értelemben, hogy $r<\Delta$ (az ellentétes eset tárgyalása megtalálható Ujhelyi [2014a]-ban).

Ha a bürokrata nem engedelmeskedik a politikusnak, megbüntethetik (például csökkentik a bérét, vagy lefokozzák): egy $e \neq E$ politika végrehajtásának költsége a bürokrata számára $h$. Az alábbiakban a $h$-t változtatva jól követhető módon fogjuk tudni vizsgálni a bürokrata feletti politikai kontroll hatását. ${ }^{5} \mathrm{~A}$ jó bürokrata valószínüsége $\pi$, és egyelőre felteszem, hogy a bürokrata típusa mindkét időszakban függetlenül realizálódik. Ez egy olyan esetnek felel meg, amikor az adott politika végrehajtásával megbízott bürokrata véletlenszerüen kerül ki egy nagy hivatalból, így a politikus egy adott bürokratával csak rövid ideig kerül kapcsolatba. E feltétel lazítását az alábbiakban tárgyalom.

A modell időzítése a következő. Az első időszak elején realizálódik a politikus és a bürokrata típusa és az $S_{1}$ világállapot. A típusok egyéni információk, de mindkét játékos megtudja a világállapotot. A szavazó nem tud meg semmit. Rossz politikus esetén realizálódik az $R_{1}$ járadék is, amit csak a politikus lát. A politikus választ egy $E_{1}$ politikát. A bürokrata ezt megfigyeli, és végrehajt egy $e_{1}$ politikát. $A$ végrehajtott politikát minden játékos megfigyeli, és az első időszaki kifizetések realizálódnak. A szavazó ezután eldönti, hogy újraválasztja-e a politikust. Ha nem választja újra, véletlenszerűen hivatalba lép egy új politikus. A második időszak

\footnotetext{
${ }^{5}$ A $h$-t tekinthetjük a büntetés maximális megengedhető szintjének is, mivel a politikus számára mindig optimális lesz a lehető legmagasabb szintű büntetés mellett elköteleződni.
} 
elején realizálódik egy új $S_{2}$ világállapot, egy új $R_{2}$ járadék és egy új bürokratatípus. A hatalmon lévő politikus választ egy $E_{2}$ politikát, a bürokrata végrehajt egy $e_{2}$ politikát, a kifizetések realizálódnak, és a játék véget ér.

Ebben a modellben a szavazó csak a bürokrata által végrehajtott politikát látja, a politikus választását nem. Ez azt a jelenséget ragadja meg, hogy a legtöbb szavazó a bürokraták, nem pedig a politikusok döntéseivel kerül közvetlen kapcsolatba. Még ha a szavazó tud is róla, hogy elfogadtak egy új, nagyszabású adócsomagot, ami ebből őt közvetlenül érinteni fogja, az a csomag részletes végrehajtása, és ez pedig a bürokratákon múlik. Vagyis amikor a szavazó a politikusok teljesítményét értékeli, ezt nagyrészt olyan kormányzati intézkedések alapján teszi, amiket a bürokrácián keresztül tapasztalt meg. ${ }^{6}$

\section{Egyensúly}

A modell megoldásához tökéletes bayesi egyensúlyt használunk. Mivel a második időszakban nincsenek stratégiai megfontolások, az egyensúly leírásához elég az első időszakot tekinteni. Az egyensúly elemei mindkét típusú politikus stratégiája, mindkét típusú bürokrata stratégiája (a politikus döntésének függvényében), valamint a szavazó vélekedése a politikus típusáról és a szavazó újraválasztási stratégiája (a végrehajtott politika függvényében). Egyensúlyban a stratégiák legjobb válaszok egymásra a szavazó vélekedése mellett, és a szavazó vélekedése racionális a stratégiák mellett.

Feltevéseink mellett a jó bürokrata mindig engedelmeskedni fog, ha a politikus jó politikát választ, a rossz bürokrata pedig engedelmeskedni fog, ha a politikus rossz politikát választ. Emellett mindkét típusú bürokrata engedelmeskedni fog a másik politikának, amennyiben a büntetés elég magas. Ez alapján, ha a politikus az $S$ világállapotban $E$ politikát választ, annak a valószínűsége, hogy a bürokrata engedelmeskedni fog neki jó politika esetén:

$\operatorname{Pr}(e=S \mid S, E=S)=\pi+(1-\pi) \mathrm{I}_{r<h} \equiv \varphi^{G}$,

rossz politika esetén pedig:

$\operatorname{Pr}(e=S \mid S, E=1-S)=\pi \mathrm{I}_{\Delta<h}+1-\pi \equiv \varphi^{B}$,

ahol $\mathrm{I}=1$, ha az indexben megjelölt feltétel igaz, egyébként 0 .

A további tárgyalás során a következő állításban leírt egyensúlyt vizsgáljuk.?

1. ÁLLÍTÁs • Egyensúlyban az első időszakban a jó politikus jó politikát választ, a rossz politikus pedig pontosan akkor választ jó politikát, ha

$R_{1}<\beta\left(\varphi^{B} \bar{R}+V_{0}\right) \frac{\varphi^{B}+\varphi^{G}-1}{\varphi^{B}+\mu\left(\varphi^{G}-1\right)}$.

${ }^{6}$ E feltevés feloldásának következményeit Ujhelyi [2014a] tárgyalja.

${ }^{7}$ Ujhelyi [2014a] megmutatja, hogy a többi egyensúlyban vagy ugyanezek lesznek a releváns kimenetek, vagy pedig az egyensúly nem robusztus egy Maskin-Tirole [2004] által javasolt perturbációra. 
A szavazó pontosan akkor választja újra a politikust, ha a végrehajtott politika jó. A második idöszakban a politikus mindig a kedvenc politikáját választja.

Az állításban leírt feltétel megértéséhez tekintsük a rossz politikust ebben az egyensúlyban. Ha jó politikát választ, a várható kifizetése $\varphi^{G} \beta\left(\varphi^{B} \bar{R}+V_{0}\right)+\left(1-\varphi^{G}\right) \mu R_{1}$, mivel $\varphi^{G}$ valószínüséggel a bürokrata engedelmeskedik, és ezért a politikust újraválasztják, $1-\varphi^{G}$ valószínüséggel pedig a bürokrata rossz politikát hajt végre, és ezért nem választják újra. Ha újraválasztják, a politikus a második időszakban rossz politikát fog választani, ezért a várható kifizetése az első tagban szereplö $\left(\varphi^{B} \bar{R}+V_{0}\right)$ kifejezés. Ha rossz politikát választ, hasonló megfontolások alapján a várható kifizetése $\left(1-\varphi^{B}\right) \beta\left(\varphi^{B} \bar{R}+V_{0}\right)+\varphi^{B} R_{1}$. A két kifejezés összehasonlításából adódik az állításban szereplő feltétel.

Az 1. ÁllítÁSBAN - mint a politikai megbízó-ügynök modellekben általában - amikor a rossz politikus járadékának realizációja nem túl nagy, a politikus „fegyelmezetten viselkedik”, vagyis az újraválasztás érdekében jó politikát választ. Ennek a valószínüsége itt $\lambda \equiv G\left\{\beta\left[\varphi^{B} \bar{R}+V_{0}\right]\left[\varphi^{B}+\varphi^{G}-1\right] /\left[\varphi^{B}+\mu\left(\varphi^{G}-1\right)\right]\right\}$. Az állítás első fő következménye abból adódik, ha megvizsgáljuk, hogy a fegyelmezett viselkedésre való ösztönzés hogyan változik a bürokrata engedelmességének $\left(\varphi^{G}\right.$, illetve $\left.\varphi^{B}\right)$ függvényében.

1. LEMMA • Minél engedelmesebb a bürokrata mind a rossz, mind a jó politikák esetén, annál valószínübb, hogy a politikus fegyelmezetten fog viselkedni.

Az, hogy a jó politikának engedelmeskedö bürokrata növeli a politikus ösztönzését a jó politika választására, talán nem meglepő. A lemma alapján viszont a rossz politikának engedelmeskedő bürokrata is ugyanezt a hatást váltja ki. Ez azért van így, mert ha újraválasztják, a rossz politikus a második időszakban biztosan rossz politikát akar majd választani. Ha a bürokrata nagyobb valószínüséggel fog engedelmeskedni ennek a rossz politikának holnap, ez növeli a politikus ösztönzését arra, hogy az újraválasztása érdekében jó politikát válasszon ma. A bürokraták engedelmessége tehát befolyásolja a választások fegyelmező erejét a politikusokra nézve.

Az ilyen típusú modellben míg az első időszaki egyensúlyi politika a választások fegyelmező erejét jelzi, addig a második időszaki politika a választások szürőszerepét mutatja. A második időszaki politika annál jobb lesz, minél jobb minőségü politikus kerül ki győztesen a választásból. Könnyen belátható, hogy annak a valószínűsége, hogy egyensúlyban a második időszaki politikus jó típusú lesz:

$\Pi^{2}+\Pi(1-\Pi)\left[\left(\varphi^{B}+\varphi^{G}\right)(1-\lambda)+\lambda\right]$.

Ebből rögtön következik a 2. LEMMA:

2. LEMMA • Adott $\lambda$ fegyelem mellett minél engedelmesebb a bürokrata mind a rossz, mind a jó politikák esetén, annál valószínübb, hogy a politikus jó minöségü lesz. 
Ez a lemma arra világít rá, hogy a bürokraták engedelmessége befolyásolja a választások szürési képességét. Minél engedelmesebb egy bürokrata, annál informatívabb lesz az általa végrehajtott politika a szavazó számára a politikus típusát illetően. Ez ismét igaz nemcsak a jó, de a rossz politikának való engedelmesség esetén is. Például, ha egy bürokrata mindig a legalacsonyabb költségü pályázónak ítéli meg a közbeszerzési szerződést, ezzel kevesebb információt nyújt a politikus minőségével kapcsolatban a szavazók számára, mint ha mindig azt csinálja, amit a politikus mond neki.

Az alábbiakban leírom, hogy a fenti állítás, illetve lemmák segítségével milyen megállapításokat tehetünk a köztisztviselöi rendszerrel kapcsolatban ebben a modellben.

\section{A bürokrácia minősége és a politikai kontroll hatása}

A köztisztviselői rendszereknek általános jellemzője, hogy javítani próbálják a bürokrácia minőségét, például köztisztviselői vizsga vagy más szakmai felvételi kritériumok segítségével. Ezt a modellben a $\pi$ paraméteren keresztül modellezhetjük. Például a köztisztviselői vizsga elősegítheti, hogy a felvett bürokraták elkötelezettek legyenek a társadalom (vagyis a szavazó) jóléte iránt, és ez növelni fogja $\pi$-t. A köztisztviselői rendszereknek egy másik jellemzője a bürokrácia feletti politikai kontroll szabályozása. Ezt a modellben a $h$ paraméter ragadja meg. Ha például a bürokraták fizetését törvényben rögzített bértábla szabályozza, vagy ha nem lehet őket könnyen elbocsátani vagy lefokozni, ezzel csökken a $h$ büntetés, amit a politikus kiszabhat egy engedetlen bürokratára. Amint arról a Bevezetőben volt szó, az Egyesült Államokban a köztisztviselői reformok első hulláma a $h$ csökkentésére (és a $\pi$ növelésére) összpontosított, miközben a második hullám a $h$ növelését tüzte ki célul, vagyis növelte a politikai kontrollt.

Ez az egyszerü modell megmutatja, hogy miként hat a köztisztviselöi törvények két alapvető vonása - a bürokraták minőségének növelése és a politikai kontroll szabályozása - a szavazó, a bürokrata és a politikus közötti játék egyensúlyára és a közpolitikai döntésekre. A mechanizmusok megértéséhez elég megfigyelni, hogy a $\pi$ és a $h$ paraméter befolyásolni fogja a bürokrata engedelmességét $\left(\varphi^{G}, \varphi^{B}\right)$. Ez alapján az 1. ÁLLíTÁs és az 1. és a 2. LEMMA segítségével leírható, hogy $\pi$ és $h$ miként hat a politikus és a bürokrata döntéseire, valamint a szavazó döntésére és ezen keresztül a megválasztott politikus minőségére.

Az alábbiakban röviden összefoglalok a modellből levezethető néhány eredményt.

Tekintsük elöször a bürokraták fölötti politikai kontroll $(h)$ változását. A kontroll csökkentése rontja a politikus első időszaki döntését. Ez az 1. LEMMÁBóL következik, mivel az alacsonyabb kontroll csökkenti a bürokrata engedelmességét. Érdekes módon ez a hatás annál erősebb, minél rosszabb a politikus (abban az értelemben, hogy nagyobb a rossz politika választásából származó várható hasznossága: $\bar{R}$ ). Minél rosszabb a politikus, annál nagyobb szükség van az újraválasztási ösztönzőre ahhoz, hogy fegyelmezetten viselkedjen, ehhez viszont nagyobb, nem pedig kisebb politikai kontrollt kell kapnia. 
A kontroll teljes hiánya $(h<r, \Delta)$ a "szelektív" $(r<h<\Delta)$ vagy a teljes $(r, \Delta<h)$ kontrollhoz képest mindig rontja a politikus minőségét. Ha egyáltalán nincs politikai kontroll, akkor a bürokrata mindig azt csinál, amit akar, és a döntése ezért semmilyen információt nem nyújt a szavazó számára a politikus minőségéröl. Ahogy a $h$ paraméter növekszik, a végrehajtott politika informatívabbá válik. Mivel azonban a politikus viselkedése is változik, ami szintén hat a szavazó szürési képességére, a kontroll növelésének hatása nem egyértelmü. A paraméterek függvényében a szelektív vagy a teljes kontroll is maximalizálhatja a politikus minőségét.

A jóléti hatások kiszámításához figyelembe kell venni a fenti megfontolásokat a politikus egyensúlyi döntésével és minőségével kapcsolatban, és ezeket össze kell vetni a bürokratákra gyakorolt közvetlen hatásokkal. A kontroll teljes hiányához képest a szelektív kontroll mindig jólétnövekedést jelent, hiszen minden dimenzióban javulást eredményez: javítja a bürokrata döntését (mivel csökkenti a jó bürokrata feletti kontrollt), és az imént leírtak alapján javítja a politikus döntését és minőségét is. A teljes kontrollnak ezzel szemben lehetnek pozitív és negatív jóléti hatásai is. Rontja a bürokrata döntését (mivel csökkenti a rossz bürokrata feletti kontrollt), viszont fegyelmezettebbé teszi a politikust, és javíthatja a politikus szürését is. Meg lehet mutatni, hogy a teljes kontroll jobb a kontroll hiányánál, ha $\pi$ alacsony, П magas, vagy ha a teljes kontroll fegyelmező ereje $(\lambda)$ magas.

Áttérve a bürokrata minőségének $(\pi)$ változására, azt találjuk, hogy magasabb $\pi$ mellett csökken annak a valószínűsége, hogy a politikus az első időszakban jó politikát fog választani. Ez az 1. LеммÁвóL következik, mert a $\pi$ növelése csökkenti a bürokrata engedelmességét a rossz politikával szemben. Mivel a politikus döntése romlik, előfordulhat, hogy a jobb minőségü bürokráciának rosszabb politikákat kell majd végrehajtania.

Ehhez hasonlóan a bürokrácia javítása ronthatja a második időszaki politikus minőségét. Magasabb $\pi$ mellett a bürokrata kevésbé engedelmeskedik egy rossz politikának, ami a 2. LEMmA alapján növeli annak a valószínűségét, hogy a rossz politikust újraválasztják. A jóléti hatások ismét ezeknek a közvetett - a politikus döntésére és minőségére gyakorolt - hatásoknak, valamint a bürokratára gyakorolt közvetlen hatásoknak az együtteséből adódnak. Meg lehet mutatni, hogy a bürokrácia minőségét érdemesebb javítani, ha $\pi$ már eleve viszonylag magas, ha a politikus $\lambda$ fegyelmezettsége alacsony, és ha a szavazók diszkontfaktorja nagyobb.

Ezek az eredmények segíthetnek racionalizálni a köztisztviselöi reformok már említett két hullámát az Egyesült Államokban. A második reformhullám, amely csökkentette a politikai kontrollt, optimális lehet, ha úgy véljük, hogy a bürokraták többsége rossz ( $\pi$ alacsony). Ez egy lehetséges értelmezése azoknak a gyakori kifogásoknak, hogy a bürokrácia „bürokratikus”, vagyis merev és alacsony hatékonyságú. Ilyenkor jólétnövelő lehet a politikai kontroll növelése - és ehhez nem szükséges, hogy a politikusok jobbak legyenek a bürokratáknál! A nagyobb kontroll akkor is javítja a politikusok döntéseit, ha $\Pi<\pi$.

Az első reformhullám ezzel szemben olyan környezetben zajlott, ahol a politikusok minőségének megítélése viszonylag rossz volt. Ilyenkor valóban jólétnövelö lehet a kontroll csökkentése, és a modell rávilágít, hogy ezt érdemes egybekötni a 
bürokrácia minőségének javításával. Ez egy lehetséges magyarázatot nyújt a köztisztviselői vizsgákra és az egyéb szakmai követelmények bevezetésére, amire szintén az első reformhullámban került sor.

Összességében a fenti modell hangsúlyozza, hogy a bürokráciát érintő reformok befolyásolják a politikusok viselkedését és minőségét - azaz befolyásolják, hogy a választások segítségével a szavazók mennyire képesek fegyelmezni, illetve szürni a politikusokat. Az alábbiakban részletesen tárgyalok két empirikus tanulmányt, amelyek ezt az általános jelenséget - a köztisztviselői törvények politikusokra gyakorolt hatását - hivatottak tesztelni.

\section{Kiterjesztés: a bürokrata mint stratégiai szereplő és az életre szóló kinevezés}

A fenti modellben a bürokratát minden időszakban véletlenszerüen választották ki, ezért nem volt lehetősége stratégiai szereplőként viselkedni. A valóságban sok bürokrata több időszakon keresztül áll kapcsolatban egy politikussal, a köztisztviselői rendszerek ezt szabályozzák is, hiszen előírják, hogy a bürokratát el lehet-e bocsátani.

Ujhelyi [2014a] részletesen tárgyal egy kiterjesztést, ahol a bürokrata stratégiai szereplő: nem figyeli meg a politikus típusát, de a választott politikából következtet rá, és ezt figyelembe véve dönti el, hogy engedelmeskedik-e a politikusnak. A politikus szintén nem látja a bürokrata típusát, de a végrehajtott politikából következtet rá, és (amenynyiben a törvény erre lehetőséget biztosít) eldönti, hogy elbocsátja a bürokratát, vagy megtartja a második időszakra. A kérdés az, hogy mi történik, ha a bürokrata kinevezése életre szól, vagyis elvesszük a politikustól az elbocsátás lehetőségét.

Az eredmények azt mutatják, hogy az életre szóló kinevezés csak rontani tud a bürokrata viselkedésén. Ilyenkor a jó és a rossz bürokraták egyaránt nagyobb valószínűséggel választanak rossz politikát. Ennek fö oka az, hogy életre szóló kinevezés esetén a rossz politika a politikus leváltásához vezethet, miközben a bürokrata megtartja az állását. Ha a bürokrata megtudja, hogy a politikus preferenciái különböznek az övétől, ösztönzése lesz rá, hogy rossz politikát végrehajtva „szabotálja” a politikust, és a leváltását okozza. Meg lehet mutatni, hogy a bürokrata viselkedésére gyakorolt negatív hatás átterjed a politikus viselkedésére is: amikor a bürokrata döntése rosszabbá válik, a politikus nagyobb valószínűséggel fog rossz politikát választani.

Mivel az életre szóló kinevezésnek ezek a negatív hatásai csak akkor jelentkeznek, ha a bürokrata stratégiai szereplőként viselkedik, ez egy lehetséges magyarázatot nyújt arra, hogy a köztisztviselöi rendszerek miért nem terjednek ki az összes bürokratára. A stratégiai viselkedés jobban érvényesülhet magas szintű bürokraták (például hivatalvezetők, miniszterek) esetében, és ezeket a pozíciókat a rendszerek általában „politikai” pozíciókként kezelik, amelyek nem járnak életre szóló kinevezéssel.

A modell egy másik következménye, hogy jólétnövelö lehet, ha a bürokraták számára lehetőséget teremtünk a szavazókkal való közvetlen kommunikációra. Ilyenkor például egy jó bürokrata, aki a politikus által választott politikából arra következtet, hogy a politikus rossz típusú, a szavazót közvetlenül tájékoztathatná erröl, ahelyett, hogy a rossz politika végrehajtásával lenne kénytelen jelezni az 
információját. Ez egy lehetséges magyarázatot nyújt arra, hogy miért helyeznek a köztisztviselöi rendszerek nagy hangsúlyt a visszaéléseket bejelentő (whistleblower) bürokraták védelmére.

\section{Köztisztviselöi törvények és kormányközi transzferek az Egyesült Államokban}

A cikk hátralevő részében részletesen bemutatom Ujhelyi [2014b] és Bostashvili-Ujhelyi [2017] föbb empirikus eredményeit. Ezek nem hivatottak a fenti modell közvetlen tesztelésére, de egy konkrét esetben - az Egyesült Államok első reformhulláma kapcsán - szemléltetik, hogy a köztisztviselői rendszer miként befolyásolhatja a politikusok viselkedését.

\section{Történeti háttér és adatok a köztisztviselői reformokról}

A köztisztviselöi rendszer empirikus vizsgálatának legkézenfekvőbb módja, hogy megfelelő intézményi variációt keresünk: egymással összehasonlítható bürokráciákat, amelyek egy részében hasonló reformokat vezettek be. Sajnos ilyen adatbázisból kevés létezik, és ahogyan azt az irodalmi áttekintésnél tárgyaltam, a meglévő adatokkal nehéz az oksági kapcsolatokat meggyözően identifikálni. E nehézségek kiküszöböléséhez új adatokat gyüjtöttem a már említett tagállami szintü amerikai reformokról.

Az Egyesült Âllamok államigazgatását a 19. század végéig és az esetek többségében a 20. század közepéig kiterjedt patronázsrendszer jellemezte. ${ }^{8}$ A megválasztott politikusok az állami állásokat fizetőeszközként használták politikai alkukban és a támogatóik jutalmazására. Egy-egy választás után az állami alkalmazottak nagy része lecserélödött, kezdve a hivatalvezetőktől egészen az utakon dolgozó közmunkásokig. A szövetségi rendszerben a patronázst a kormányzat különböző szintjein az erös pártrendszer tartotta össze. A tagállamok szintjén a patronázs a kormányzó kezében futott össze, és az állások elosztása az ő pártján belüli alkukon keresztül zajlott.

Ebben a rendszerben sokan aggasztónak tartották a bürokráciában a stabilitás és a folytonosság teljes hiányát, hiszen az államigazgatás nagy része minden egyes választás után kicserélődött. A történészek és az államigazgatási kutatók leírásai szerint a reformhullám alulról indult, a szavazóktól és különböző civil szervezetektől, és összekapcsolódott az úgynevezett progresszív korszakban a kormányzat javítását célzó különböző kezdeményezésekkel (lásd Mosher [1982] és Ingraham [1995]). Néhány sikertelen próbálkozás után az 1883-as Pendleton-törvény szövetségi szinten bevezette a köztisztviselöi rendszert, amelynek alapvető elemei, hogy 1. a dolgozók felvételének szakmai érdemek (felvételi vizsga) alapján kell történnie, és 2 . a dolgozók nem kötelezhetők politikai szolgáltatások nyújtására, illetve ennek elmulasztásáért nem bocsáthatják el öket. A rendszer ezenkívül létrehozott egy független „Köztisztviselői Bizottságot” a szabályok betartatására.

\footnotetext{
${ }^{8}$ A patronázsrendszert dokumentáló, különösen érdekes történeti munka Tolchin-Tolchin [1971] és Sorauf [1956].
} 
A következő száz évben a köztisztviselöi rendszert a Pendleton-törvényhez nagyon hasonló keretben lassan átvették a tagállamok és a helyi önkormányzatok is. ${ }^{9}$ Erről a folyamatról, a reformok tagállami szintü bevezetéséről gyüjtöttem új adatokat.

$\mathrm{Az}$ adatgyüjtés a következő kérdésekre koncentrált: pontosan mikor vezették be tagállami szinten a köztisztviselői törvényt (illetve bevezettek-e ilyen törvényt)? Tartalmazott-e a törvény valamilyen, a Pendleton-törvénytöl lényegesen különböző elemet? Tartalmazott-e a törvény valamilyen elöírást az alsóbb (önkormányzati) szintekre vonatkozóan? Eltörölték-e vagy érdemben módosították-e a törvényt a későbbi években? E kérdések megválaszolásához sok száz levéltári anyagot, kormányzati dokumentumot és korabeli újságcikket kellett átvizsgálni (a részleteket lásd Ujhelyi [2014b]-ben). A törvények bevezetésének időpontját az 1. táblázat tartalmazza.

Mint az 1. táblázatban láható, a bevezetés időpontjában jelentős varianciát tapasztalunk a tagállamok között. Az első törvény néhány hónappal követte a Pendletontörvényt (New York állam, 1883), míg az államok többségében a 20. század közepéig nem volt köztisztviselői rendszer. Texas az egyetlen, ahol egyáltalán nem vezettek be ilyen törvényt.

A $z$ adatgyüjtés során azt találtam, hogy a bevezetett törvények nagyon hasonlók voltak a szövetségi Pendleton-törvényhez, egy kivétellel nem tartalmaztak elöŕást az önkormányzatokra vonatkozóan, és a legtöbb esetben a törvényt (legalábbis a 20. század végéig) nem vonták vissza. Sok tagállamban voltak egyes hivatalok, amelyek az állami rendszer bevezetését megelőzően is használtak valamilyen típusú köztisztviselői rendszert dolgozóik szabályozására (például 1939/1940-ben a szövetségi társadalombiztosítási törvény módosítása a szövetségi jóléti segélyek feltételeként írta elő, hogy az ilyen segélyek elosztásával foglalkozó dolgozóknak minden kormányzati szinten köztisztviselői szabályok alapján kell müködniük). Az 1. táblázat az átfogó, minden hivatalára kiterjedő köztisztviselöi rendszer bevezetésére vonatkozik.

Az elemzés során a vizsgált időszak az 1942-1983 közötti periódus lesz, vagyis a reformok hatását abból a 28 reformból fogjuk identifikálni, amelyekre az 1943 -as virginiai és az 1977-es mississippi reform között került sor. Az 1942-es kezdő dátumra azért van szükség, mert itt kezdődik a kormányzati kiadások idősora. E dátum előnye, hogy kimarad a már említett szövetségi társadalombiztosítási törvény módosításának a hatása. Az időszak másik végén az 1983-as dátumot választottam. Mivel szövetségi szinten 1978-ban indult a második reformhullám (amely lazította a köztisztviselői szabályokat), fontos, hogy ne mossuk össze a két típusú reformot. Bár tagállami szinten a köztisztviselői rendszer lazítása csak 1996-ban kezdődött, az 1989-es nyugat-virginiai reform már más szövetségi szabályozási környezetben született, ezért úgy döntöttem, hogy ezt kihagyom az elemzésből. A vizsgált időszak 1983-as lezárása lehetővé teszi, hogy az 1977-ig tartó reformok öt évvel késleltetett hatásait is megvizsgáljuk.

\footnotetext{
${ }^{9}$ Az amerikai szövetségi rendszer fontos eleme számunkra, hogy a szabályozás tekintetében a tagállamok és a helyi önkormányzatok nagy szabadságot élveznek. A szövetségi szinten bevezetett köztisztviselői rendszer nem vonatkozott a tagállami bürokráciákra, és a tagállami szinten bevezetett rendszerek általában nem vonatkoztak az önkormányzatokra.
} 
1. táblázat

Átfogó köztisztviselői rendszer bevezetésének éve az Egyesült Államok tagállamaiban

\begin{tabular}{|c|c|c|c|}
\hline Tagállam & Év & Tagállam & Év \\
\hline Nyugat-Virginia & 1989 & Észak-Karolina & 1949 \\
\hline Mississippi & 1977 & Georgia & 1945 \\
\hline Montana & 1976 & Missouri & 1945 \\
\hline Nebraska & 1975 & Oregon & 1945 \\
\hline Észak-Dakota & 1975 & Virginia & 1943 \\
\hline Dél-Dakota & 1973 & Indiana & 1941 \\
\hline Arkansas & 1969 & Kansas & 1941 \\
\hline Dél-Karolina & 1969 & Michigan & $1941^{\star \star}$ \\
\hline Arizona & 1968 & Alabama & 1939 \\
\hline Delaware & 1968 & Minnesota & 1939 \\
\hline Florida & 1967 & Rhode Island & 1939 \\
\hline Idaho & 1967 & Connecticut & 1937 \\
\hline Iowa & 1967 & Maine & 1937 \\
\hline Pennsylvania & 1963 & Tennessee & 1937 \\
\hline Utah & 1963 & Maryland & 1921 \\
\hline Új-Mexikó & 1961 & Colorado & 1919 \\
\hline Washington & 1961 & Kalifornia & 1913 \\
\hline Kentucky & 1960 & Ohio & 1913 \\
\hline Oklahoma & 1959 & New Jersey & 1908 \\
\hline Wyoming & 1957 & Illinois & 1905 \\
\hline Nevada & 1953 & Wisconsin & 1905 \\
\hline Louisiana & $1952^{*}$ & Massachusetts & 1885 \\
\hline New Hampshire & 1950 & New York & 1883 \\
\hline Vermont & 1950 & & \\
\hline
\end{tabular}

* Korábbi rendszer 1940-1948 között.

** Korábbi rendszer 1937-1939 között.

Forrás: Ujhelyi [2014b].

\section{Hipotézis és specifikáció}

A köztisztviselöi rendszer bevezetése függetlenítette a bürokráciát, és ezzel korlátozta a politikus képességét a politikák végrehajtásának befolyásolására. Kormányzati kiadások esetén ez azt jelenti, hogy a politikusnak a reform után sok esetben csak korlátozott módja volt annak befolyásolására, hogy a pénzeket pontosan hogyan költsék el - például hogy ki kapja a jóléti juttatásokat, hogy hova építsenek egy új autópályát, hogy ki nyerje a közbeszerzési pályázatokat, stb. Ez csökkentette a tagállami szintü kormányzati kiadásokkal elérhető politikai nyereséget a politikusok számára. A szövetségi szabályozás 
sajátossága azonban, hogy a tagállami szintű rendszer a legtöbb esetben nem érintette az önkormányzatokat. A tagállami politikusok számára tehát nem változott az önkormányzatokon keresztül megszerezhető politikai haszon. Ez alapján azt várhatjuk, hogy a tagállami politikusoknak a határon ösztönzésük lesz az állami pénzeket az önkormányzatokon és nem pedig a tagállami bürokrácián keresztül elkölteni.

A tagállami politikusok számára az önkormányzatokon keresztül történő pénzköltés módja a kormányközi transzfer (intergovernmental transfer). Ilyenkor a tagállam pénzt ad az önkormányzatnak, és az önkormányzat bizonyos mértékig szabad kezet kap e források elköltésével kapcsolatban. A fentiek alapján azt várjuk, hogy a köztisztviselöi rendszer bevezetése növelhette ezeknek a transzfereknek az arányát, hiszen a transzferek segítségével a tagállami politikusok megkerülhetik a megreformált tagállami bürokráciát a tagállami források elköltésénél.

E gondolat teszteléséhez a következő egyszerű panelregresszióból indulok ki:

$Y_{s t}=\alpha K T R_{s t}+\beta X_{s t}+\gamma_{s}+\delta_{t}+\varepsilon_{s t}$

ahol $Y_{s t}$ a kormányközi transzferek mértéke $s$ tagállamban a $t$-edik évben, $K T R_{s t}$ egy indikátor, amely 1 -et vesz fel, ha érvényben van a köztisztviselői rendszer, $X$ a kontrollváltozók vektora, $\gamma_{s}$ és $\delta_{t}$ tagállam és év fix hatások, $\varepsilon_{s t}$ a hibatag, $\alpha$ és $\beta$ pedig paraméterek. A köztisztviselői rendszer hatását az $\alpha$ paraméter fogja mérni: ez azt mutatja, hogy miként változnak a kormányközi transzferek egy adott tagállamban $t-1$ és $t$ között, ha a $t$-edik évben lépett érvénybe a köztisztviselői rendszer.

A függő változó képzéséhez a tagállami kormányzattól az alacsonyabb kormányzati egységek (városi és megyei önkormányzatok, iskolakörzetek) felé irányuló kormányközi transzfereket elosztom a teljes tagállami kormányzati kiadással az adott évben. ${ }^{10}$ Mivel a költségvetési ciklus július 1-től június 30-ig tart, az adott költségvetési évhez tartozó kiadásokat az előző naptári évhez rendelem hozzá (például a $t=1970$-hez rendelt kiadások az 1970. július 1. és 1971. június 30. közötti időszaknak felelnek meg - ezek azok a kiadások, amelyeket a leginkább befolyásolhat az 1970-ben életbe lépő reform).

A z $X$ kontrollváltozók kiválasztásánál a fö szempont, hogy megpróbáljuk kiszűrni a köztisztviselői rendszer bevezetésével korreláló azon változókat, amelyek a kormányközi transzferek mértékét is befolyásolhatják. Mint azt a fentiekben leírtam, a reform fő okának a történészek és az államigazgatási kutatók az Egyesült Államok progresszív korszakából induló, alulról jövő ,jó kormányzat” mozgalmat tekintik. A szavazóknak a reform iránti igénye összefügghet a gazdasági fejlettséggel (például ha rosszul teljesítő gazdaság esetén nagyobb az igény a kormányzat hatékony müködésére), a politikai környezettel (például ha az egyik párt elkötelezettebb a reform iránt), a szavazók ideológiai összetételével és a népesség összetételével (például, ha a fiatal szavazók jobban támogatják a reformot). E tényezők mindegyike korrelálhat a kormányközi transzferekkel is, ezért fontos kontrollálni

${ }^{10}$ Ezzel kiszűröm a teljes kiadás változásának hatásait. Ujhelyi [2014b] megmutatja, hogy hasonló eredményeket kapunk akkor is, ha a függő változót nem osztjuk el a teljes kiadással. A változók pontos forrását és képzésük részleteit, valamint a különböző összefoglaló statisztikákat lásd az eredeti cikkben. 
rájuk. Az $X$ vektor tartalmazza a lakosság jövedelmét és annak négyzetét, a tagállamok népességét és annak négyzetét, az 5-17 év közötti és a 65 év feletti népesség arányát, párterősségi mutatókat, ${ }^{11}$ valamint egy gyakran használt mérőszámot a szavazók ideológiájának mérésére (Berry és szerzőtársai [1998]).

Egy az irodalomban megtalálható másik elmélet szerint a patronázsrendszer felszámolása és a köztisztviselői rendszer elterjedése összefügg a politikai és gazdasági erőviszonyok vidék és a városok közötti átrendeződésével. E megközelítés szerint a patronázsrendszer fóként a városoknak kedvezett, és a vidéki érdekcsoportok fontos szerepet játszottak a felszámolásában. Mivel a kormányközi transzferek szintén korrelálhatnak a vidéki területek fejlődésével, ennek kiszürésére kontrollálok a városi lakosság arányára is.

\section{Fö eredmények}

A fenti regresszió eredményeit a 2. táblázat tartalmazza. A teljes mintában 48 kontinentális tagállam szerepel. ${ }^{12} \mathrm{Az}$ (1) oszlopban azt találjuk, hogy a köztisztviselői rendszer bevezetése 3 százalékponttal növeli a kormányközi transzferek arányát a teljes kiadásban. Ez a hatás statisztikailag szignifikáns és nagyságrendileg is jelentős: a függő változó átlagos értéke az adatokban 27,2 százalék. A (2)-(4) oszlopokban azt látjuk, hogy a hatás stabil marad különböző kontrollváltozók mellett és a minta későbbi felére leszükített elemzésben is (a szavazói ideológia változója csak 1960-tól áll rendelkezésre).

Ezek az eredmények alátámasztják a fenti történetet. Úgy tünik, hogy a köztisztviselői rendszer hatására a kormányzati kiadások valóban nagyobb arányban áramlottak az alacsonyabb, meg nem reformált bürokráciák felé.

A 2. táblázat oksági értelmezését olyan tényezők veszélyeztethetik, amelyek (a kontrollváltozók mellett is) korrelálnak a reform bevezetésével, és együtt mozognak a kormányközi kiadásokkal. Például képzeljük el, hogy egy adott tagállamban decentralizálásra kerül sor. Ez meggyengíti a központi kormányzatot, amely így kevésbé tud ellenállni a reformmozgalomnak, és kénytelen bevezetni a köztisztviselöi rendszert. Ezzel párhuzamosan a decentralizálás természetes módon növelheti a központtól a helyi önkormányzatokhoz érkező kormányközi transzfereket. Ebben a történetben is pozitív korreláció keletkezik a köztisztviselöi reform és a kormányközi transzferek között, de a hatás nem oksági kapcsolat.

Az iménti történet és az ehhez hasonló magyarázatok jellegzetessége, hogy ebben az esetben nem feltétlenül várnánk egyidejű korrelációt a köztisztviselői rendszer és a kormányközi kiadások között. Sokkal valószínübb például, hogy a decentralizálás először megnöveli a kormányközi kiadásokat, viszont a köztisztviselői reform

${ }^{11}$ A párterősségi mutatók a következők: indikátorok arra, hogy az állami törvényhozás egységes republikánus vagy demokrata irányítás alatt áll-e (az adott pártnak többsége van-e az alsó- és a felsőházban is), valamint a kormányzó pártállása.

${ }^{12}$ Az ilyen típusú regressziókból ki szokás hagyni Nebraskát és Minnesotát, mert itt a vizsgált időszakban a kormányzat politikai szerkezete jelentősen eltért a többi tagállamétól. 
2. táblázat

Kormányközi transzferek és a köztisztviselői rendszer

\begin{tabular}{lcccc}
\hline & $(1)$ & $(2)$ & $(3)$ & $(4)$ \\
\cline { 2 - 5 } & Teljes minta & Teljes minta & 1960 után & 1960 után \\
\hline KTR & $0,030^{* *}$ & $0,032^{\star * *}$ & $0,032^{* *}$ & $0,039^{\star * *}$ \\
Párterősség & $(0,012)$ & $(0,012)$ & $(0,013)$ & $(0,012)$ \\
Városi lakosság & & $\mathrm{X}$ & $\mathrm{X}$ \\
Szavazói ideológia & & $\mathrm{X}$ & $\mathrm{X}$ \\
$R^{2}$ & & & & $\mathrm{X}$ \\
$N$ & 0,16 & 0,18 & 0,19 & 0,23 \\
\hline
\end{tabular}

Megjegyzés: a függő változó a kormányközi kiadások aránya a tagállami kiadásokban. Minden regresszió tartalmaz konstanst, tagállam és év fix hatásokat, a tagállami népesség logaritmusát és annak négyzetét, az egy főre jutó reáljövedelmet és annak négyzetét, valamint az 5-17 év közötti, illetve a 65 év feletti népesség arányát. A párterősség változói a törvényhozás egységes demokrata, illetve republikánus irányítása és a kormányzó pártállása. A teljes minta 48 kontinentális tagállamot tartalmaz 1941-1983 között. Az 1960 utáni minta az 1960-1983 közötti időszakot fedi le. Zárójelben robusztus standard hibák tagállami szinten klaszterezve. ${ }^{\star} p<0,1,{ }^{* *} p<0,05,{ }^{* * *} p<0,01$.

Forrás: Ujhelyi [2014b].

iránti ellenállás gyengülése - és így a rendszer bevezetése - csak késleltetve jelentkezik. Ez viszont tesztelhető! A fenti regresszióban a KTR változót helyettesíthetjük a reform bevezetését megelőző (és akár az azt követő) indikátorokkal, és megvizsgálhatjuk, hogy a köztisztviselői rendszer hatása valóban az adott évi kiadásokban mutatkozik meg, vagy esetleg már korábban is.

Ehhez a következő regressziót becsültem:

$$
Y_{s t}=\sum_{-5 \leq \tau \leq 5, \tau \neq 1} \alpha_{\tau} K T R_{s t, \tau}+\beta X_{s t}+\gamma_{s}+\delta_{t}+\varepsilon_{s t}
$$

ahol $-5<\tau<5$ esetén $K T R_{s t, \tau}=1$, ha a köztisztviselöi rendszert a $(t+\tau)$-adik évben vezetik be, $K T R_{s t,-5}=1$, ha a rendszert legalább öt éve vezették be, és $K T R_{s t, 5}=1$, ha a rendszert öt vagy annál több év múlva fogják bevezetni. Ebben a regresszióban $\tau>0$ esetén az $\alpha_{\tau}$ paraméter azt méri, hogy a köztisztviselöi rendszernek volt-e „hatása” $\tau$ évvel azelőtt, hogy bevezették volna. A $\tau<0$ értékekhez tartozó $\alpha_{\tau}$ paraméterek a reform késleltetett hatásait, illetve a hatás tartósságát mérik (a hatásokat minden esetben a kihagyott $\tau=1$ kategóriához, vagyis a reform bevezetését megelőző évhez képest mérjük).

A fenti regresszió eredményeit az 1. ábra foglalja össze. A vízszintes tengely a $\tau$ értékeit mutatja, az ábra pedig az ezekhez tartozó becsült paraméterértékeket és a 95 százalékos konfidenciaintervallumot jelzi. Azt találjuk, hogy a reform bevezetését megelőző négy évben az $\alpha_{\tau}$ paraméterek értéke szinte pontosan 0: a reformnak semmilyen hatása nem volt a kormányközi kiadásokra azelött, hogy életbe lépett volna. Ez kizárja a decentralizálással kapcsolatos fenti történetet és minden más olyan 
alternatív magyarázatot, amelyikben a kormányközi kiadások nem pontosan a reform évében változnak. Mint látható, a kormányközi kiadások a reform évében megugranak, és a következő néhány évben stabilan ezen a magasabb szinten maradnak. Úgy tűnik, a köztisztviselői rendszer tartós ösztönzőket teremtett a politikusok számára a kormányközi transzferek megemelésére.

1. ábra

A köztisztviselői rendszer „hatása” a bevezetés előtt és után

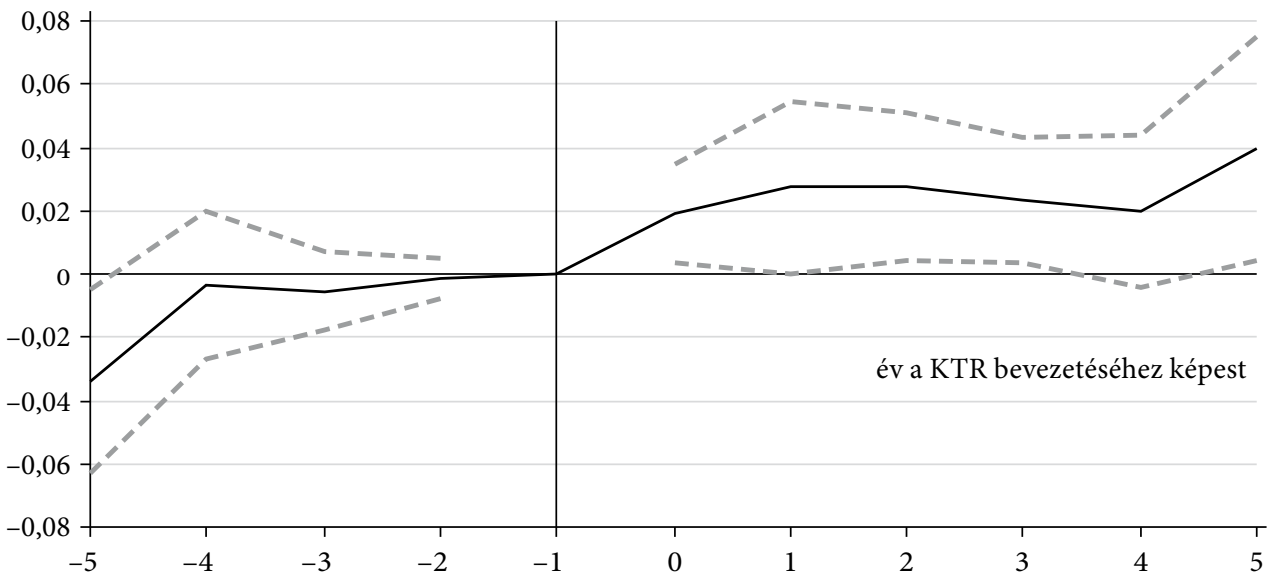

Megjegyzés: az ábra az $\alpha_{\tau}$ becsült értékeit és a hozzájuk tartozó 95 százalékos konfidenciaintervallumot mutatja. A vízszintes tengelyen a negatív értékek a bevezetést megelőző éveket jelölik. A kontrollváltozók tartalmazzák a párterősség, a városi lakosság és a szavazói ideológia változóit, valamint a 2. táblázatban felsorolt összes változót. A becslési minta az 1960 utáni időszak.

Forrás: Ujhelyi [2014b].

\section{További eredmények és robusztusságvizsgálat}

Ujhelyi [2014b] számos módon vizsgálja, hogy az imént bemutatott eredmények robusztusak-e, illetve hogy indokolt-e az az értelmezés, hogy a kormányközi kiadások növekedése a politikusok válaszát tükrözi a köztisztviselöi rendszer által teremtett korlátokra. Ezek közül itt kettőről számolok be röviden.

Egy releváns különbség a tagállamok között, hogy a köztisztviselöi rendszer vezetője mennyire független a hatalmon lévő politikusoktól - nevezetesen a tagállami kormányzótól. Vannak tagállamok, ahol a bürokrácia személyzeti vezetőjét a kormányzó nevezi ki, és vannak, ahol nem (ezekben általában a független „Köztisztviselöi Bizottság" nevezi ki). Erre a különbségre tekinthetünk úgy, mint egy intenzitásbeli különbségre az egyes köztisztviselői rendszerek között. A kormányzótól független személyzeti vezető alatt működő rendszer biztosítja a legnagyobb függetlenséget a bürokrácia számára. Ha a fenti eredmények értelmezése helyes volt, akkor azt várjuk, hogy a független személyzeti vezető tovább növeli a kormányközi 
transzferek arányát. Az adatok pontosan ezt mutatják: bár a köztisztviselői rendszer bevezetése független személyzeti vezető nélkül is növeli a kormányközi kiadásokat, a független személyzeti vezető szignifikánsan erősíti ezt a hatást. Úgy tűnik, független személyzeti vezető esetén a politikusoknak különösen nagy az ösztönzése a tagállami bürokrácia megkerülésére.

Az irodalomban felmerült, hogy bizonyos esetekben a köztisztviselöi rendszer bevezetése nem a hatalmon lévő politikusok ellenére történik, hanem ellenkezőleg, az ő érdekeiket szolgálja (lásd például Hanssen [2004]). A rendszer bevezetésével ugyanis a hatalmon lévő politikusok bebetonozhatják az általuk patronált dolgozókat, és megnehezíthetik, hogy egy esetleges új adminisztráció megvalósítsa a politikai céljait.

Ha a hatalmon lévő politikusok a köztisztviselői rendszerrel a saját embereiknek akarnak kedvezni, akkor azt várnánk, hogy a rendszer bevezetésekor nőni fog az alkalmazottak száma és/vagy bére. Mivel a részmunkaidős dolgozók patronázs szempontjából különösen vonzók (adott költségvetési korlát mellett több támogatót lehet állással jutalmazni), ebben az esetben különösen náluk számíthatunk növekedésre. Az itt vizsgált környezetben az adatok ennek éppen az ellenkezőjét mutatják. Azt találjuk, hogy a köztisztviselöi rendszer csökkenti az alkalmazottak számát, különösen a részmunkaidős alkalmazottakét, és nem jár szignifikáns bérnövekedéssel. Ez inkább azzal az értelmezéssel konzisztens, hogy a köztisztviselői rendszer karcsúsította és talán hatékonyabbá tette a bürokráciát.

\section{A köztisztviselöi rendszer hatása a kormányzati beruházásokra}

A fentiekben azt láttuk, hogy a köztisztviselői rendszer növelte a kormányközi transzferek arányát a kormányzati kiadásokban. Felmerül a kérdés, hogy ez milyen hatással volt a kiadások összegére.

Rauch [1995] amerikai városokat vizsgált az 1902-1931 közötti időszakban, és azt találta, hogy a városi köztisztviselői rendszer ezekben a városokban növelte az infrastruktúra-fejlesztési kiadásokat (például útépítés, csatornázás, vízhálózat). Az általam vizsgált tagállami szintű reformok ezzel ellentétes eredményeket mutatnak. Ujhelyi [2014b] különböző regressziókat futtat az állami tőkekiadásokra, és konzisztensen negatív hatásokat talál. Úgy tűnik, a köztisztviselői rendszer bevezetése csökkentette a tagállami beruházásokat - akár külön a tagállami kormányzatot tekintjük, akár a tagállami és az önkormányzati beruházások összegét.

E különbségeknek Rauch [1995] eredményeihez képest számos magyarázata lehet, hiszen más időszakot vizsgálunk, és a tagállami szintü regressziókban számos olyan tényezöre tudunk kontrollálni, amelyekre Rauchnak nem voltak adatai. Egy érdekes lehetőség, hogy a különbség a különböző - városi vagy tagállami - szinteken végrehajtott reformokból fakad. A városok „alatt” jellemzően nincs kormányzati egység, amelyhez egy politikus forrásokat tudna transzferálni a köztisztviselöi reformok megkerülése érdekében. A tagállami politikusoknak ezzel szemben rendelkezésükre állnak az önkormányzatok, így nagyobb mozgásterük van a reformra való reagálásra, mint a városi politikusoknak. 
A következőkben tovább vizsgálom a köztisztviselői rendszer hatását a kormányzati beruházásokra egy konkrét kategóriában - az útépítési kiadásokban.

Összességében az eredmények alátámasztják a korábban bemutatott modell fö üzenetét: a köztisztviselői törvények befolyásolják a politikusok viselkedését. Szabályozási szempontból az eredmények arra utalnak, hogy a reform bevezetésénél fontos átgondolni, hogy mely kormányzati egységek maradjanak a köztisztviselői rendszeren kívül. Minden kihagyott kormányzati egység egy lehetséges utat jelent a politikus számára a rendszer megkerülésére.

\section{A köztisztviselői rendszer hatása az útépítési kiadások politikai ciklusára}

A köztisztviselői rendszer bevezetésekor a fö cél az államigazgatás stabilizálása volt. A patronázsrendszerben a bürokrácia jelentős része lecserélődött, amikor egy új párt nyerte a választásokat, és ez akadályozta a kormányzati tevékenység folytonosságát. A következőkben Bostashvili-Ujhelyi [2017] eredményeit ismertetem, ahol megmutatom, hogy a köztisztviselői rendszer egy másik értelemben is „stabilizálhatja” a kormányzati müködést: a politikusok döntésein keresztül. Nevezetesen, a köztisztviselői rendszer csökkentheti a kormányzati kiadások választási ciklushoz való igazítását.

\section{A köztisztviselői rendszer és a politikai költségvetési ciklusok}

Az irodalomban a politikai költségvetési ciklus (political budget cycle) azt a jelenséget írja le, hogy a politikusok bizonyos feltételek mellett ösztönözve vannak arra, hogy a kiadásokat vagy a bevételeket a választási ciklushoz igazítsák. Például kifizetődő lehet a választások elött csökkenteni az adókat vagy megemelni bizonyos kiadásokat (lásd például Persson-Tabellini [2003], Brender-Drazen [2005], Shi-Svensson [2006], Alt-Lassen [2006], Drazen-Eslava [2010]).

Az irodalom megmutatja, hogy az ilyen típusú ciklus nem általános jelenség, hanem függ olyan tényezőktöl, mint a demokrácia fejlettsége, a választási törvények vagy a politikai átláthatóság, és természetesen attól is, hogy melyik kiadási vagy bevételi kategóriát tekintjük. Bár a bürokrácia fontos közvetítő a politikusok és a választók között, a bürokratikus intézmények hatását a politikai költségvetési ciklusokra még nem vizsgálta senki.

Bostashvili-Ujhelyi [2017] a fentiekben elemzett köztisztviselöi reformok hatását elemzi az amerikai útépítési kiadások politikai ciklusára. Az alapötlet egyszerü. Egy politikus a választások előtt szavazatokat nyerhet azáltal, hogy a megfelelő helyen épít vagy újít fel egy útszakaszt, vagy kampánytámogatást nyerhet azáltal, hogy a megfelelö vállalkozót bízza meg ezzel a munkával. Patronázsrendszerben ez viszonylag egyszerü, mivel az útépítést irányító hivatalt kényszerítheti arra, hogy a projektet a számára megfelelő módon szervezzék. Köztisztviselői rendszerben a politikusoknak jóval kevesebb lehetőségük van a lebonyolítás részleteibe való beavatkozásra. Miután 
kiutalták a forrásokat, a projekt szervezéséről független bürokraták döntenek szakmai szempontok alapján. Köztisztviselői rendszerben ezért a politikus számára sokkal nehezebb az ilyen beruházásokból politikai tőkét kovácsolni. Ez alapján azt várjuk, hogy a politikai ciklusokra való ösztönzés kisebb lesz köztisztviselői rendszerben, mint patronázsrendszerben.

\section{Háttér és adatok}

Az alábbiakban a tagállami szintű útépítési kiadásokat vizsgáljuk. Ez egy tág kategória, amely magában foglalja az utak és a hozzájuk tartozó szerkezetek (hidak, alagutak, kompjáratok, jelzőlámpák stb.) építését és karbantartását, beleértve a hótakarítást, az utak szépítését és egyéb járulékos tevékenységeket. A tagállami költségvetésekben az útépítési kiadások jelentős tételnek számítanak: az 1950-es és 1960as években az összes kiadás 25-35 százalékát, a későbbi években pedig körülbelül 10 százalékát tették ki egy átlagos tagállamban.

$\mathrm{Az}$ amerikai útfinanszírozási rendszernek több eleme is van, ami politikai szempontból különösen vonzóvá teszi az útépítést a tagállami kormányzatok számára. $\mathrm{Az}$ utak építéséért és karbantartásáért a tagállamok felelősek, és az ő hatáskörükbe tartozik a projektek kiválasztása és megszervezése. Ugyanakkor a finanszírozás nagy részét a szövetségi kormányzat nyújtja. 1956 óta a források a Highway Trust Fundtól (autópálya-építési trösztalaptól) hívhatók le, és a legtöbb projekt esetében ez a költségek 75-90 százalékát fedezi. Vagyis miközben az útépítési projektek a tagállami politikusok számára politikai tőkét jelentenek - hiszen nyilvánvalóan fontosak a szavazók számára -, a projektek költségeit nagyrészt külső forrásokból finanszírozhatják. Ez azt sugallja, hogy az útépítési kiadásokban a politikai költségvetési ciklus létrehozása vonzó lehet a tagállami politikusok számára.

A tagállami kormányzatokban az útépítési tevékenység a közlekedési hivatalok hatáskörébe tartozik. Annak vizsgálatához, hogy a bürokrácia szabályozása miként hat az útépítési kiadásokra, érdemes külön megvizsgálni ezeknek a hivataloknak a személyzeti rendszerét. Bár az átfogó tagállami köztisztviselői rendszer természetesen ezekre a hivatalokra is vonatkozott, elöfordult, hogy a hivatal már az átfogó rendszer bevezetése előtt is rendelkezett saját köztisztviselői rendszerrel. Bostashvili-Ujhelyi [2017] adatokat gyüjtött erröl, és azt találta, hogy öt olyan tagállam volt, amelyikben a releváns időszakban a közlekedési hivatal már az átfogó köztisztviselöi rendszer bevezetése előtt is rendelkezett saját rendszerrel (Dél-Karolina, Arizona, Idaho, Washing ton és Texas). Az alábbiakban bemutatok empirikus eredményeket mind az átfogó köztisztviselöi rendszer, mind a közlekedési hivatalokra érvényes köztisztviselői rendszer hatásaira vonatkozóan.

A vizsgált időszak 1960-1995. Az 1960-as kezdőévre egyrészt az adatok elérhetősége miatt van szükség, másrészt ez biztosítja, hogy az autópálya-építési trösztalap 1956-os létrehozása - ami vélhetően sok tagállami politikus számára megváltoztatta az útépítéssel kapcsolatos politikai kalkulációt - nem befolyásolja az eredményeket. Az 1995ös záró év biztosítja, hogy kellően hosszú panel álljon rendelkezésre a késleltetett függő 
változós regressziók futtatásához (lásd alább) - anélkül, hogy a mintában szerepelne a köztisztviselöi rendszerek lazítását célzó második reformhullám (ami állami szinten az 1996-os georgiai reformmal kezdődött). Bostashvili-Ujhelyi [2017] megmutatja, hogy az alábbi eredmények rövidebb elemzési időszakra is érvényesek.

A függő változót az egy före jutó útépítési kiadások reálértékével mérjük. Kihagyjuk a kormányközi kiadásokat, hiszen ezekre a fent tárgyalt eredmények alapján külön politikai kalkuláció vonatkozhat. Útépítési kiadások esetén a tagállami kormányzatok a kiadások 85 százalékát közvetlenül (nem kormányközi transzferek formájában) nyújtják.

A politikai költségvetési ciklusok irodalma általában a fő végrehajtó hatalom - jelen esetben a tagállami kormányzó - választási ciklusára koncentrál, mivel ennek a politikai szereplőnek van a legnagyobb hatása a kiadásokra. A tagállami kormányzókat általában négy évre választják, de a minta korai részében előfordult néhány kétéves ciklus is. Az alábbi elemzésből kihagyjuk ezeket a kétéves ciklusokat, hiszen a politikai kiadások időzítése ezekben várhatóan más lesz. A vizsgált adatok ez alapján 359 választási ciklust tartalmaznak 44 államban.

\section{Specifikáció}

A politikai költségvetési ciklusok irodalmában a ciklus tesztelésére használt standard regresszió a következő alakot ölti:

$y_{s t}=\sum_{\tau=-2}^{0} \alpha_{\tau} E l e_{s t}^{\tau}+\delta y_{t-1}+\rho X_{s t}+\lambda_{s}+\mu_{t}+\varepsilon_{s t}$,

ahol $y_{s t}$ a vizsgált kiadás mértéke az $s$-edik tagállamban a $t$-edik évben, $E l e_{s t}^{\tau}$ egy olyan indikátor, amely 1 -et vesz fel a következő választástól számított $\tau$-adik évben (a kihagyott kategória a $\tau=-3$, vagyis a választást követő év), $X$ a kontrollváltozók vektora, $\lambda_{s}$ és $\mu_{t}$ pedig tagállam és év fix hatások. Mivel az adott évi kiadások a választási ciklustól függetlenül is függhetnek a kiadások előző évi szintjétől, ebben az irodalomban standard megoldás kontrollálni a függő változó késleltetett értékére is $\left(y_{t-1}\right)$ A ciklusokat ebben a regresszióban az $\alpha$ paraméterek mérik, például az $\alpha_{0}>0$ azt jelzi, hogy a választás évében nagyobb a kiadás a választás utáni évhez képest.

Annak tesztelésére, hogy a politikai költségvetési ciklust befolyásolja-e a köztisztviselői rendszer, a fenti regressziót a következőképpen módosíthatjuk:

$y_{s t}=\sum_{\tau=-2}^{0} \alpha_{\tau} E l e_{s t}^{\tau}+\beta_{\tau} E l e_{s t}^{\tau} \times K T R_{s t}+\gamma K T R_{s t}+\delta y_{t-1}+\rho X_{s t}+\lambda_{s}+\mu_{t}+\varepsilon_{s t}$,

ahol $K T R_{s t}=1$, ha köztisztviselöi rendszer müködik az adott államban az adott évben. Ebben a regresszióban az $\alpha$ paraméterek azt mérik, hogy van-e politikai költségvetési ciklus az útépítési kiadásokban patronázsrendszer mellett (vagyis amikor $K T R_{s t}=0$ ). A $\beta$ paraméterek azt mérik, hogy a ciklus különbözik-e köztisztviselöi rendszer és patronázsrendszer esetén. Ha például azt kapjuk, hogy $\alpha_{0}>0$ és $\beta_{0}<0$, ez azt jelzi, hogy a patronázsrendszer esetén a választási évben megnőnek a kiadások, a köztisztviselöi rendszer viszont tompítja ezt a hatást. 
A becslési módszer megválasztásánál figyelembe kell venni, hogy a fenti regreszszió tartalmazza a függő változó késleltetett értékét. Mivel a regresszió fix hatást is tartalmaz, rövid panel esetében az OLS-becslés torzított eredményekhez vezet. Ilyenkor a standard megoldás a Holtz-Eakin és szerzötársai [1988] és Arellano-Bond [1991] által javasolt GMM becslési eljárás (a politikai ciklusok irodalmában lásd például Shi-Svensson [2006] és Drazen-Eslava [2010]). A mi esetünkben a panel hosszúsága (35 év) valószínűleg azt jelenti, hogy a torzítás mértéke alacsony, miközben a GMMeljárásnak más hátrányai lehetnek (Judson-Owen [1999] például 30 időszaknál hoszszabb panel esetén OLS-becslést javasol). Az alábbiakban OLS-eredményeket mutatunk be, és Bostashvili-Ujhelyi [2017] megmutatja, hogy ezek az eredmények robusztusak akkor is, ha a GMM-eljárást használjuk.

A fenti regresszió identifikálása szempontjából különösen hasznos az itt vizsgált környezet. Először is, a vizsgált intézményi változásnak nemcsak keresztmetszeti, hanem időbeli dimenziója is van, hiszen a tagállamok változtatták a rendszerüket a vizsgált időszak során. Ez azt jelenti, hogy számos korábbi tanulmánnyal ellentétben itt nem pusztán keresztmetszeti összehasonlítást végzünk a különböző költségvetési ciklusok között. Másodszor, az amerikai környezetben a választások időpontjai exogén módon rögzítettek. A költségvetési ciklusok irodalmában, különösen országok összehasonlításakor, jelentős problémák adódnak abból, ha a választások időpontja változhat. Harmadszor, a vizsgált intézményt - a köztisztviselői rendszert - objektív módon számszerüsítjük a bevezetési év alapján. Ezzel elkerüljük azokat az értelmezési problémákat, amelyek különböző szubjektív mutatók (például a gyakran használt korrupciós vagy transzparenciaindexek) használatakor merülnek fel (lásd Donchev-Ujhelyi [2014]).

\section{Eredmények}

A fenti regresszió eredményeit a 3. táblázat mutatja. Az (1) oszlop nem tartalmazza a köztisztviselői rendszer bevezetését, vagyis az átlagos politikai költségvetési ciklust teszteli. Az eredmények azt mutatják, hogy nincs ilyen ciklus: az útépítési kiadások a választási ciklus egyik évében sem különböznek statisztikailag a választást követő évtől.

A (2) oszlopban interaktáljuk a választási ciklust a KTR változóval. Az eredmények jelentős méretü és statisztikailag szignifikáns politikai költségvetési ciklust jeleznek patronázsrendszer esetén. A becsült paraméterek azt mutatják, hogy $K T R=0$ mellett választási évben az egy före jutó útépítési kiadás 38,41 dollárral magasabb, mint a választást követő évben. A kiadás a választást megelőző évben is magasabb, 29,81 dollárral. Ezek az értékek átlagosan 12, illetve 9 százalékos növekedésnek felelnek meg a választás utáni évhez képest. ${ }^{13}$

Az eredmények azt mutatják, hogy ez a költségvetési ciklus csak patronázsrendszer esetén van jelen, köztisztviselöi rendszer esetén nincs. A $K T R$ változóval való interakciók a választási év és az azt megelöző év esetében statisztikailag szignifikánsak,

\footnotetext{
${ }^{13}$ Mivel az útépítési projektek hónapokig vagy akár évekig is eltarthatnak, nem meglepő, hogy nemcsak a választási évben, hanem már az azt megelőző évben is növekedést tapasztalunk a kiadásokban.
} 


\section{3. táblázat}

Politikai ciklusok az útépítési kiadásokban köztisztviselői és patronázsrendszerben

\begin{tabular}{|c|c|c|c|}
\hline & (1) & $(2)$ & (3) \\
\hline$E l e^{0}$ & $\begin{array}{c}6,51 \\
(4,01)\end{array}$ & $\begin{array}{l}38,41^{* * *} \\
(9,40)\end{array}$ & $\begin{array}{l}40,37^{\star * *} \\
(12,96)\end{array}$ \\
\hline$E l e^{-1}$ & $\begin{array}{c}1,05 \\
(4,22)\end{array}$ & $\begin{array}{l}29,81^{\star *} \\
(12,42)\end{array}$ & $\begin{array}{l}39,43^{\star *} \\
(15,95)\end{array}$ \\
\hline$E l e^{-2}$ & $\begin{array}{c}-6,12 \\
(4,03)\end{array}$ & $\begin{array}{c}7,35 \\
(14,77)\end{array}$ & $\begin{array}{c}13,46 \\
(18,91)\end{array}$ \\
\hline$E l e^{0} \times K T R$ & & $\begin{array}{c}-35,95^{\star * *} \\
(9,60)\end{array}$ & $\begin{array}{l}-37,27^{\star \star \star} \\
(13,50)\end{array}$ \\
\hline$E l e^{-1} \times K T R$ & & $\begin{array}{c}-32,94^{* *} \\
(12,72)\end{array}$ & $\begin{array}{c}-42,67^{\star *} \\
(16,27)\end{array}$ \\
\hline$E l e^{-2} \times K T R$ & & $\begin{array}{c}-15,34 \\
(14,55)\end{array}$ & $\begin{array}{c}-21,78 \\
(18,75)\end{array}$ \\
\hline KTR & & $\begin{array}{l}17,57^{*} \\
(8,79)\end{array}$ & $\begin{array}{c}18,87^{\star} \\
(11,12)\end{array}$ \\
\hline$K T R$ változó szintje & & átfogó & közlekedési hivatal \\
\hline$R^{2}$ & 0,68 & 0,68 & 0,68 \\
\hline$N$ & 1387 & 1387 & 1387 \\
\hline
\end{tabular}

Megjegyzés: OLS-regressziók. A függő változó az egy főre jutó útépítési reálkiadások. Minden regresszió tartalmaz konstanst, tagállam és év fix hatásokat, a függő változó késleltetett értékét, a tagállami népesség logaritmusát és annak négyzetét, az egy főre jutó reáljövedelmet és annak négyzetét, az 5-17 év közötti, illetve a 65 év feletti népesség arányát, párterösségi változókat (a törvényhozás egységes demokrata, illetve republikánus irányítása és a kormányzó pártállása), a városi lakosság arányát, illetve a szavazók ideológiáját mérő Berry és szerzőtársai [1998]-féle mutatót. Zárójelben robusztus standard hibák tagállami szinten klaszterezve.

${ }^{\star} p<0,1,{ }^{* *} p<0,05,{ }^{* * *} p<0,01$.

Forrás: Bostashvili-Ujhelyi [2017].

és a fő hatásokhoz képest hasonló nagyságúak, de ellentétes előjelüek. Köztisztviselöi rendszer esetén a kiadások emelkedése mindössze 2,46 $(=38,41-35,95)$ dollár a választási évben; $-3,13$ (=29,81 -32,94) a választást megelőző évben, és statisztikailag ezek egyike sem szignifikáns. Ezeket az eredményeket szemlélteti a 2. ábra, amelyen a költségvetési ciklust ábrázoljuk patronázs- (bal oldali ábra) és köztisztviselői rendszer (jobb oldali ábra) esetében. Az ábrából jól látható, ahogy a köztisztviselői rendszer stabilizálja az útépítési kiadásokat a választási ciklus folyamán.

A 3. táblázat (3) oszlopa az átfogó köztisztviselői rendszer helyett a közlekedési hivatalokra vonatkozó köztisztviselői rendszert tekinti. Mint látható, ezzel a változóval is hasonló eredményeket kapunk.

Mit tudunk mondani az olyan helyzetekről, amikor a közlekedési hivatal rendelkezik saját köztisztviselői rendszerrel, a tagállam egészében viszont még nincs bevezetve az átfogó rendszer? Egyfelöl lehet, hogy a politikus szempontjából a közlekedési hivatal rendszere számít igazán, hiszen az útépítési projekteket ennek a hivatalnak a bürokratái 
2. ábra

Politikai ciklusok az útépítési kiadásokban köztisztviselői és patronázsrendszerben
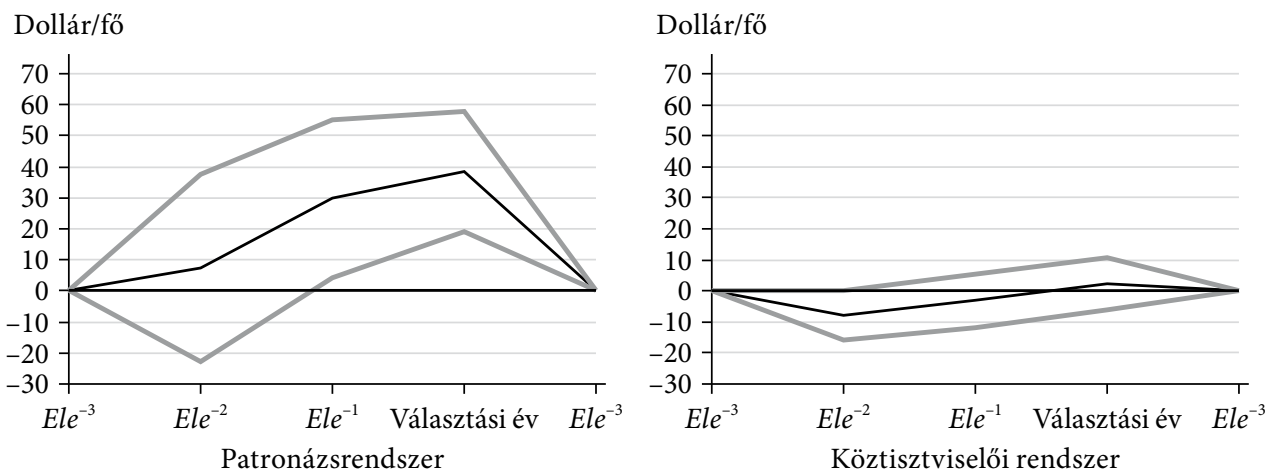

Megjegyzés: az ábra a politikai ciklust mutatja az egy före jutó útépítési reálkiadásokban a 2. táblázat (2) oszlopa alapján patronázsrendszerben (bal oldali ábra) és köztisztviselöi rendszerben (jobb oldali ábra). Mindkét esetben a viszonyítási alap a választás utáni év, amit 0-ra normalizáltunk. A 95 százalékos konfidenciaintervallumot a szürke vonalak mutatják. Forrás: Bostashvili-Ujhelyi [2017].

irányítják, így a felettük gyakorolt kontroll mértéke dönti el, hogy mekkora politikai hasznot lehet húzni ezekből a kiadásokból. Másfelől viszont az is lehet, hogy egy adott hivatalra érvényes köztisztviselői rendszer minőségileg különbözik az átfogó rendszertől. Például lehet, hogy a hivatalspecifikus rendszert nem tartatják be olyan szigorúan, mint az átfogó rendszert. Vagy lehet, hogy egy ilyen rendszert könnyebb a politikus számára megkerülni, például ha egy adott projektben több hivatalnak kell együttmüködnie - a közlekedési hivatal mellett, mondjuk, a mezőgazdasággal vagy az egészségüggyel foglalkozó hivatalok bürokratáinak -, és a többi hivatal bürokratái nem tartoznak a köztisztviselői rendszer alá.

E kérdés vizsgálatához megbecsültük a fenti regressziót úgy is, hogy mindkét KTRváltozót egyszerre szerepeltettük, a választási ciklussal való interakciókkal együtt. Hangsúlyozni kell, hogy a hivatalspecifikus és az átfogó rendszer hatása közötti különbséget kisszámú megfigyelésből identifikáljuk, hiszen viszonylag kevés olyan időszak van az adatokban, amikor hivatalspecifikus rendszer már van, de átfogó rendszer még nincs.

Az eredményeket a 3. ábrán mutatjuk be. A felső bal oldali ábra a patronázsrendszer melletti helyzetet mutatja, és jól látható az előzőekben is tapasztalt politikai ciklus. A felső jobb oldali ábrán a közlekedési hivatalnak már van köztisztviselöi rendszere, a tagállam egészének még nincs. Itt a ciklus „laposabbá” válik, méghozzá a választást megelőző évi kiadásemelkedés mérséklődik jelentősen. Az alsó ábrán az átfogó köztisztviselői rendszerbeli helyzet látható, és itt a ciklus teljesen kisimul. Ebben az értelemben a hivatalspecifikus rendszer mérsékeli a politikai költségvetési ciklust, de csak az átfogó rendszer bevezetése szünteti azt meg teljesen.

Összességében ezek az eredmények ismét alátámasztják, hogy a köztisztviselői rendszer hatásainak egy része a politikusok viselkedésén keresztül jelentkezik. Ebben az esetben azt találtuk, hogy a patronázsrendszer felváltása egy ilyen rendszerrel nemcsak a bürokrácia müködését, de a politikusok viselkedését is „stabilizálja.” 


\section{3. ábra}

Politikai ciklusok az útépítési kiadásokban hivatalspecifikus, átfogó köztisztviselői és patronázsrendszer mellett
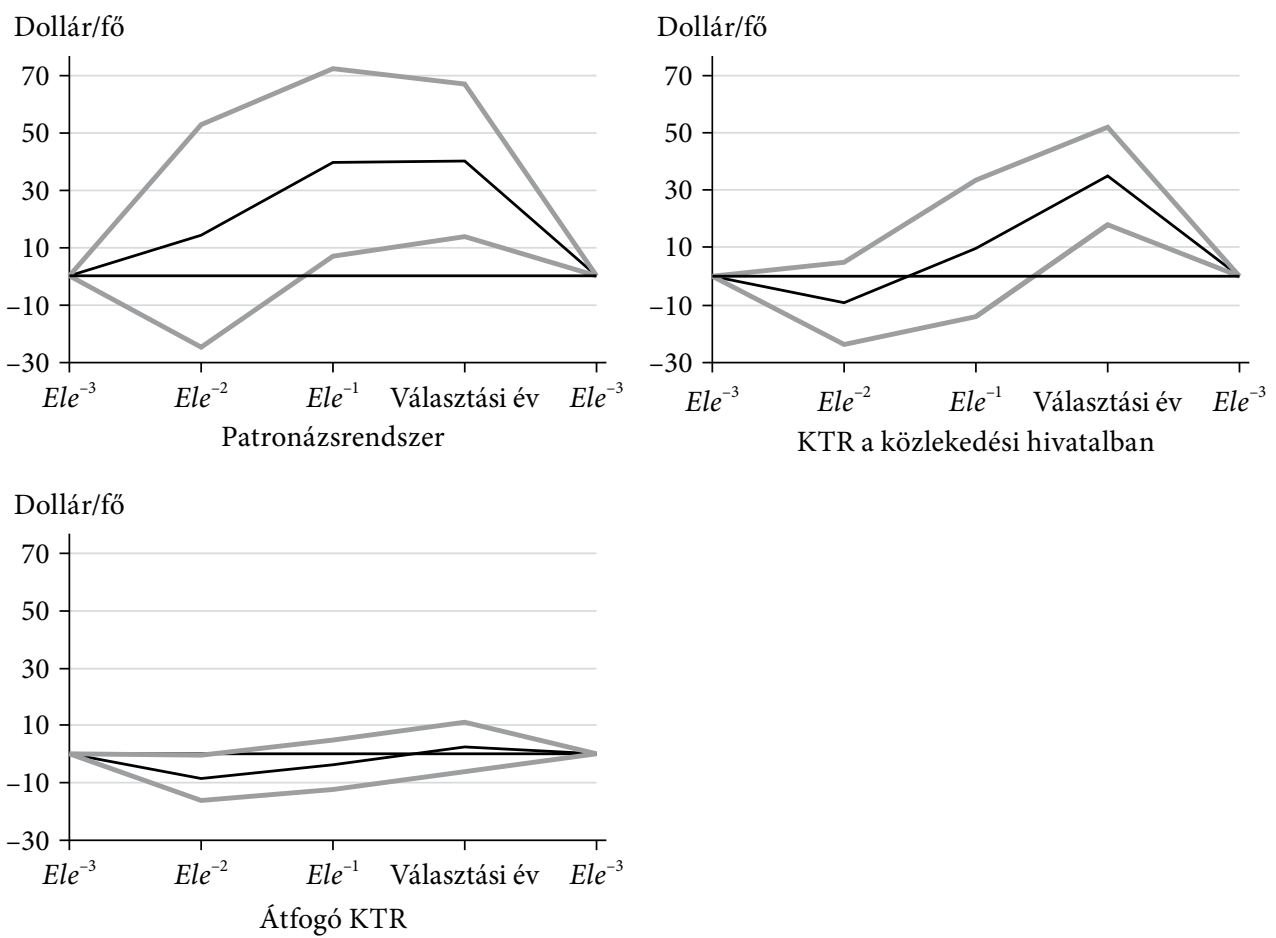

Megjegyzés: az ábra a politikai ciklust mutatja az egy főre jutó útépítési reálkiadásokban, ha a regresszióban egyszerre szerepel a hivatalspecifikus és az átfogó $K T R$ változó. Az ábra a becslésből következő ciklust mutatja patronázs-, hivatalspecifikus köztisztviselői rendszer és átfogó köztisztviselöi rendszer esetén. Mindegyik esetben a viszonyítási alap a választás utáni év, amit 0-ra normalizáltunk. A 95 százalékos konfidenciaintervallumot a szürke vonalak mutatják. Forrás: Bostashvili-Ujhelyi [2017].

\section{Jövőbeli kutatási irányok}

Más politikai szereplőkhöz képest (politikusok, érdekcsoportok, választók) a bürokrácia irodalma sok szempontból hiányos, sok a nyitott kérdés és a kiaknázatlan terület. Különösen keveset tudunk a bürokratikus intézmények hatásairól - a fentiekben leírt eredmények is ebben az irányban tesznek elörelépést a köztisztviselöi törvények hatásvizsgálatával kapcsolatban. Zárásként megfogalmazok három gondolatot a jövőbeli kutatási irányokkal kapcsolatban.

Először is, nagy szükség van ebben az irodalomban ügyes identifikációs lehetőségek felkutatására, vagyis olyan természetes kísérletekre, ahol valamilyen intézményi változás keretében véletlenszerüség keletkezik, és ez kiaknázható. Egy friss példa erre Ornaghi [2016] PhD-disszertációja, amely a 20. század elején a 
rendőrségek személyzeti rendszerét vizsgálja amerikai városokban. Néhány állam elöírta, hogy egy bizonyos népességszám fölött a városi rendőröknek köztisztviselői rendszerben kell dolgozniuk, így a népességhatár két oldalán (éppen alatta, éppen fölötte) lévő városok összehasonlításával egy természetes kísérlet adódik, amelyben a köztisztviselöi rendszer hatása szakadásos regressziós (regression discontinuity) módszerekkel elemezhető.

Másodszor, mint azt a fentiekben hangsúlyoztam, fontos korlát az irodalomban, hogy kevés az adat az egymással összehasonlítható intézményi berendezkedésekről és szabályokról. Nagy igény van ezért új adatok gyüjtésére. Itt a tudományos hozzájárulás akkor lesz igazán értékes, ha minél kisebb egységekről sikerül adatokat szerezni (például megyékről, városokról vagy akár egyes hivatalokról).

Végül, mint a politikai gazdaságtan más területein is, a bürokráciával kapcsolatban is viszonylag sokat tudunk az Egyesült Államokról, és viszonylag keveset más országokról. A szakmában nagy igény van rá, hogy más országok államigazgatási rendszereivel kapcsolatban is gyüljenek adatok és keletkezzenek empirikus eredmények. Biztos vagyok benne, hogy a magyar bürokrácia intézményeivel kapcsolatosan is vannak eddig még ki nem használt kutatási lehetőségek, és ezen a területen az eredmények iránti nemzetközi kereslet egyelöre jóval meghaladja a kínálatot.

\section{Hivatkozások}

Alesina, A.-Tabellini, G. [2007]: Bureaucrats or Politicians? Part I: A single policy task. American Economic Review, Vol. 97. No. 1. 169-179. o. https://doi.org/10.12570002 82807780323578.

Alt, J. E.-Lassen, D. D. [2006]: Transparency, Political Polarization, and Political Budget Cycles in OECD Countries. American Journal of Political Science, Vol. 50. No. 3. 530-550. o. https://doi.org/10.1111/j.1540-5907.2006.00200.x.

Arellano, M.-Bond, S. [1991]: Some Tests of Specification for Panel Data: Monte Carlo Evidence and an Application to Employment Equations. Review of Economic Studies, Vol. 58. No. 2. 277-297. o. https://doi.org/10.2307/2297968.

Berry, W. D.-Ringquist, E. J.-Fording, R. C.-Hanson, R. L. [1998]: Measuring Citizen and Government Ideology in the American States, 1960-93. American Journal of Political Science, Vol. 42. No. 1. 327-348. o. https://doi.org/10.2307/2991759.

Bertrand, M.-Burgess, R.-Chawla, A.-Xu, G. [2016]: The Costs of Bureaucratic Rigidity: Evidence from the Indian Administrative Service. Working Paper, http://www.guoxu. org/docs/ias.pdf.

BESLEY, T. [2012]: A jó kormányzat politikai gazdaságtana. Alinea Kiadó, Budapest.

Besley, T.-CAse, A. [2003]: Political institutions and policy choices: Evidence from the United States. Journal of Economic Literature, Vol. 41. No. 1. 7-73. o. https://doi.org/10. 1257/002205103321544693.

Besley, T.-McLaren, J. [1993]: Taxes and Bribery: The Role of Wage Incentives. Economic Journal, Vol. 103. 119-141. o. https://doi.org/10.2307/2234340.

Bostashvili, D.-Ujhelyi, G. [2017]: Political Budget Cycles and the Civil Service: Evidence from Highway Spending in US States. Working Paper. 
Brender, A.-Drazen, A. [2005]: Political Budget Cycles in New versus Established Democracies. Journal of Monetary Economics, Vol. 52. No. 7. 1271-1295. o. https://doi. org/10.1016/j.jmoneco.2005.04.004.

Conte, S.-Knight, B. [2011]: Government Form and Public Spending: Theory and Evidence from US Municipalities. American Economic Journal: Economic Policy, Vol. 3. No. 3. 82-112. o. https://doi.org/10.1257/pol.3.3.82.

Dal Bo, E.-Finan, F.-Rossi, M. A. [2013]: Strengthening State Capabilities: The Role of Financial Incentives in the Call to Public Service. Quarterly Journal of Economics, Vol. 128. No. 3. 1169-1218. o. https://doi.org/10.1093/qje/qjt008.

Donchev, D.-Ujhelyi, G. [2014]: What Do Corruption Indices Measure? Economics and Politics, Vol. 26. No. 2. 309-331. o. https://doi.org/10.1111/ecpo.12037.

Drazen, A.-Eslava, M. [2010]: Electoral Manipulation via Voter-Friendly Spending: Theory and Evidence. Journal of Development Economics, Vol. 92. No. 1. 39-52. o. https://doi. org/10.1016/j.jdeveco.2009.01.001.

Epstein, D.-O’Halloran, S. [1999]: Delegating Powers. A Transaction Cost Politics Approach to Policy Making under Separate Powers. Cambridge University Press, Cambridge, UK, https://doi.org/10.1017/cbo9780511609312.

Folke, O.-Hirano, S.-Snyder, J. M., JR. [2011]: Patronage and Elections in US States. American Political Science Review, Vol. 105. No. 3. 567-585. o. https://doi.org/10.1017/ s0003055411000256.

Fox, J.-Jordan, S. V. [2011]: Delegation and Accountability. Journal of Politics, Vol. 73. No. 3. 831-844. o. https://doi.org/10.1017/s0022381611000491.

Gailmard, S.-Patty, J. W. [2007]: Slackers and Zealots: Civil Service, Policy Discretion, and Bureaucratic Expertise. American Journal of Political Science, Vol. 51. No. 4. 873-889. o. https://doi.org/10.1111/j.1540-5907.2007.00286.x.

HANSSEN, F. A. [2004]: Is there a politically optimal level of judicial independence? American Economic Review, Vol. 94. No. 3. 712-729. o. https://doi.org/10.1257/0002828 041464470.

Holtz-Eakin, D.-Newey, W.-Rosen, H. S. [1988]: Estimating vector autoregressions with panel data. Econometrica, Vol. 56. No. 6. 1371-1395. o. https://doi.org/10.2307/1913103.

Ingraham, P. W. [1995]: The Foundation of Merit: Public Service in American Democracy. Johns Hopkins University Press, Baltimore.

Judson, R. A.-Owen, A. L. [1999]: Estimating Dynamic Panel Data Models: A Guide for Macroeconomists. Economics Letters, Vol. 65. No. 1.9-15. o. https://doi.org/10.1016/s01651765(99)00130-5.

Krause, G. A.-Lewis, D. E.-Douglas, J. W. [2006]: Political appointments, civil service systems, and bureaucratic competence: Organizational balancing and executive branch revenue forecasts in the American states. American Journal of Political Science, Vol. 50. No. 3. 770-787. o. https://doi.org/10.1111/j.1540-5907.2006.00215.x.

Leaver, C. [2009]: Bureaucratic Minimal Squawk Behavior: Theory and Evidence from Regulatory Agencies. American Economic Review, Vol. 99. No. 3. 572-607. o. https://doi. org/10.1257/aer.99.3.572.

Maskin, E.-Tirole, J. [2004]: The Politician and the Judge: Accountability in Government. American Economic Review, Vol. 94. No. 4. 1034-1054. o. https://doi.org/10.1257/ 0002828042002606.

Mosher, F. [1982]: Democracy and the public service. 2. kiadás. Oxford University Press, New York. 
Ornaghi, A. [2016]: Civil Service Reforms: Evidence from U.S. Police Departments. Working Paper.

Persson, T.-Tabellini, G. [2003]: The Economic Effects of Constitutions. MIT Press, Cambridge, MA.

Prendergast, C. [2007]: The Motivation and Bias of Bureaucrats. American Economic Review, Vol. 97. No. 1. 180-196. o. https://doi.org/10.1257/000282807780323532.

RAUCH, J. E. [1995]: Bureaucracy, Infrastructure, and Economic Growth: Evidence form US Cities During the Progressive Era. American Economic Review, Vol. 85. No. 4. 968-979. o. https://doi.org/10.3386/w4973.

RAUCH, J. E.-Evans, P. B. [2000]: Bureaucratic structure and bureaucratic performance in less developed countries. Journal of Public Economics, Vol. 75. No. 1. 49-71. o.

Shi, M.-Svensson, J. [2006]: Political Budget Cycles: Do They Differ across Countries and Why? Journal of Public Economics, Vol. 90. No. 8-9. 1367-1389. o. https://doi.org/10.1016/j. jpubeco.2005.09.009.

Sorauf, F. J. [1956]: State Patronage in a Rural County. American Political Science Review, Vol. 50. No. 4. 1046-1056. o. https://doi.org/10.2307/1951334.

TING, M. M. [2012]: Legislatures, Bureaucracies, and Distributive Spending. American Political Science Review, Vol. 106. No. 2. 367-385. o. https://doi.org/10.1017/s0003055412000081.

Tolchin, M.-Tolchin, S. [1971]: To the Victor... Political Patronage from the Clubhouse to the White House. Random House, New York.

Ujhelyi Gergely [2014a]: Civil Service Reform. Journal of Public Economics, Vol. 118. 15-25. o. https://doi.org/10.2139/ssrn.2150381.

Ujhelyi Gergely [2014b]: Civil Service Rules and Policy Choices: Evidence from US State Governments. American Economic Journal: Economic Policy, Vol. 6. No. 2. 338-380. o. https://doi.org/10.1257/pol.6.2.338.

VlAiCU, R.-WHALlEy, A. [2016]: Hierarchical accountability in government. Journal of Public Economics, Vol. 134. 85-99. o. https://doi.org/10.1016/j.jpubeco.2015.12.011. 